\title{
China - Anti-Dumping and Countervailing Duty Measures on Broiler Products from the United States: How the chickens came home to roost
}

\author{
THOMAS J. PRUSA* \\ Rutgers University and NBER \\ EDWIN VERMULST** \\ VVGB Advocatenfoo
}

\begin{abstract}
The WTO Panel report on China-Anti-dumping and Countervailing Duty Measures on Broiler Products from the United States was circulated to Members on 2 August 2013. In the report, the Panel examined a variety of issues challenged by the United States under various provisions of the General Agreement on Tariffs and Trade 1994, the Anti-dumping Agreement and the Agreement on Subsidies and Countervailing Measures. The Panel upheld the United States' claims on the majority of the issues, which covered certain procedural aspects of the anti-dumping and countervailing investigations such as the right to disclosure of 'essential facts', as well as the substantive determinations including costing issues, the imposition of the 'all others' rate on the basis of 'facts available', the price effects' analyses, the sufficiency of the public notices, and others. Notably the costing issues that came up in the case, although decided mostly on procedural grounds, provide food for thought, and are likely to feature again in future disputes.
\end{abstract}

\section{Introduction}

On 8 December 2011, the United States (US) requested the Dispute Settlement Body (DSB) of the World Trade Organization (WTO) to establish a Panel to examine People's Republic of China's (China) imposition of anti-dumping (AD) and countervailing (CVD) measures on broiler products from the US, as set forth in the Ministry of Commerce of the People's Republic of China (MOFCOM) Notice No. 8 [2010] (preliminary AD determination), Notice No. 26 [2010] (preliminary

\footnotetext{
*E-mail: prusa@econ.rutgers.edu.

**E-mail: edwin.vermulst@vvgb-law.com.

The views expressed in this paper are those of the authors and all omissions and errors are also of the authors. The authors would like to thank Juhi Sud and Madison Meng for their helpful assistance in the preparation of this paper.
} 
CVD determination), Notice No. 51 [2010] (final AD determination), and Notice No. 52 [2010] (final CVD determination), ${ }^{1}$ including their annexes as well as various aspects of the proceedings leading up to the imposition of the measures. The US claimed that the AD and CVD measures were inconsistent with China's commitments and obligations under several provisions of the General Agreement on Tariffs and Trade 1994 (GATT, 1994), the Anti-Dumping Agreement (ADA) and the Agreement on Subsidies and Countervailing Measures (SCM Agreement). ${ }^{2}$

Following the US' request, the DSB established a Panel on 20 January 2012 and the Panel report was circulated to Members on 2 August $2013 .{ }^{3}$ In the report, a variety of issues was examined by the Panel in evaluating the 14 claims brought by the US. The Panel concluded that China acted inconsistently with its WTO obligations on most of the issued challenged by the US. The Panel found that MOFCOM failed to meet the requirements of Articles 6.2, 6.5.1, and 6.9 of the ADA and Article 12.4.1 of the SCM Agreement for all three of the procedural claims. It also ruled for the US on the majority of the issues that arose in nine other claims with respect to a number of substantive determinations made by MOFCOM in the AD and CVD investigations, such as costing issues, the sufficiency of the public notices, the price effects' analyses, and the imposition of the 'all others' rate on the basis of 'facts available'. Additionally, given the Panel's findings on the procedural and substantive claims, the Panel also ruled against China on the two consequential claims under Article 1 of the ADA and Article 10 of the SCM Agreement.

Many of the US' claims were similar to those raised by the US in an earlier WTO dispute brought by the US against China on the latter's imposition of anti-dumping and countervailing duties on US exports of grain oriented flat-rolled electrical steel. ${ }^{4}$ To the extent that we have already analyzed these in one of our previous articles, ${ }^{5}$ we will not analyze them in this report again, although we discuss them in detail in Section 3 below, as it is our view that the reader should be able to read our report as a stand-alone overview of the Panel report. However, our

1 The preliminary AD determination and preliminary CVD determination are together called 'preliminary determinations' in this paper. Similarly, the final AD determination and final CVD determination are together termed as 'final determinations'.

2 China - Anti-Dumping and Countervailing Duty Measures on Broiler Products from the United States. Panel Report, WT/DS427/R, adopted 25 September 2013, WT/DS/427/R/Add.1, adopted 25 September 2013 [hereinafter China-Broiler Products]. The consultations requested by the US with China on 20 September 2011 did not resolve the dispute.

3 On 23 November 2012, the Chairman of the Panel informed the DSB that its work could not be completed within six months. After consultations with the parties to the dispute, the deadline for the Panel was changed to the end of June 2013.

4 Appellate Body Report, China - Countervailing and Anti-Dumping Duties on Grain Oriented FlatRolled Electrical Steel from the United States, WT/DS414/AB/R, adopted 16 November 2012.

5 See Thomas J. Prusa and Edwin Vermulst, 'China-Countervailing and Anti-dumping Duties on Grain Oriented Flat-rolled Electrical Steel from the United States: Exporting US AD/CVD methodologies through WTO dispute settlement?', 13:2 World Trade Review, 229-266 (2014). 
legal and economic analysis in Section 4 will rather focus on the novel issues that came up in this dispute, mostly relating to how to cost various chicken parts. The reader already familiar with the Panel report itself could therefore skip Section 3 and move directly to Section 4. Arguably, the most interesting issue in this investigation was how to reasonably appraise the value of different parts of the broiler. The different parts might well have different values, but in this case those values dramatically differed depending on consumer preferences in different markets. The US producers' valuation reflected the product preferences in the US market and thus heavily valued chicken breasts and treated certain broiler products, specifically chicken paws, as holding little or no value. This approach created serious issues in the $\mathrm{AD}$ investigation because the largest volume broiler part exported to China was chicken paws, a product that had little value in the US market, but significant value in the Chinese market. Although the Panel was able to decide most of the US' claims in this context on procedural grounds, it did discuss in passing some of the conceptual issues involved that are likely to come up again in future WTO dispute settlement proceedings. Finally, we conclude in Section 5 with a few comments on the political economy dimensions of this dispute and the specter of WTO consistent tit-for-tat trade disputes.

\section{Factual background to the dispute}

The original $\mathrm{AD}$ and CVD investigations were initiated by MOFCOM on 27 September 2009 pursuant to an application filed by the China Animal Agriculture Association (CAAA) on behalf of the Chinese domestic industry on 14 August 2009. A supplemental application was filed by CAAA on 13 October 2009 alleging additional subsidy programs, which MOFCOM decided to investigate in the CVD investigation.

The preliminary $\mathrm{AD}$ and CVD determinations were published by MOFCOM on 5 February 2010 and 28 April 2010, respectively. In the preliminary AD determination, MOFCOM concluded that the US exporters were dumping and the dumping had caused material injury to the Chinese domestic industry. In the preliminary CVD determination, MOFCOM found that the imported broiler products from the US were subsidized and had caused material injury to the domestic broiler industry. ${ }^{6}$

The final AD and CVD determinations were issued by MOFCOM on 26 September 2010 and 30 August 2010 respectively. MOFCOM reaffirmed the findings that it reached in the preliminary determinations with respect to the dumping/subsidization of the subject imports and the resulting material injury to the domestic industry.

6 The period of investigation (POI) is 1 July 2008 to 30 June 2009 for the AD and CVD investigations; and 1 January 2006 to 30 June 2009 for the injury to the domestic industry in the two investigations. 
Table 1. ADD and CVD margins

\begin{tabular}{|c|c|c|c|c|}
\hline \multirow[b]{2}{*}{ Respondent } & \multicolumn{2}{|l|}{$\mathrm{ADD}$ rate } & \multicolumn{2}{|l|}{ CVD rate } \\
\hline & Preliminary & Final & Preliminary & Final \\
\hline Pilgrim's Pride & $80.5 \%$ & $53.4 \%$ & $4.9 \%$ & $5.1 \%$ \\
\hline Tyson & $43.1 \%$ & $50.3 \%$ & $11.2 \%$ & $12.5 \%$ \\
\hline Keystone & $44.0 \%$ & $50.3 \%$ & $3.8 \%$ & $4.0 \%$ \\
\hline $\begin{array}{l}\text { Registered firms but } \\
\text { not selected for } \\
\text { individual examination }\end{array}$ & $64.5 \%$ & $51.8 \%$ & $6.1 \%$ & $7.4 \%$ \\
\hline All others & $105.4 \%$ & $105.4 \%$ & $31.4 \%$ & $30.3 \%$ \\
\hline
\end{tabular}

Source: Panel Report, China-Broiler Products, paras. 2.4-2.5.

The preliminary and final $\mathrm{AD}$ and CVD duty rates are presented in the table above.

On 20 September 2011, the US requested WTO consultations with China concerning these measures. The two parties held the consultations on 28 October 2011 but were not able to resolve the dispute. Subsequently, the US requested the establishment of a Panel to examine the matter, which was composed on 24 May 2012.7 The Panel issued its final report to the parties on 25 June 2013 and it was adopted by the DSB on 25 September 2013.

\section{Key issues examined in the Panel report}

In its submission to the Panel, the US claimed that China had committed 14 violations under various provisions of the GATT 1994, the ADA, and the SCM Agreement. Of the 14 alleged violations, six of them dealt solely with articles of the ADA, two of them were only challenged under articles of the SCM Agreement, while the others involved combinations of provisions of the GATT 1994, the ADA, and/or the SCM Agreement. ${ }^{8}$ All of the alleged violations are discussed in this paper but we have emphasized certain issues that we consider to be more significant than others.

This section includes two main parts and they set out the issues that were raised with respect to (1) the procedural aspects of the investigations and (2) the substantive issues including the reasoning and conclusions for the $\mathrm{AD}$ determinations, the CVD determinations, and the injury determinations in the $\mathrm{AD}$ and CVD investigations.

7 Third parties to the Panel proceedings were Chile, the European Union, Japan, Mexico, Norway, the Kingdom of Saudi Arabia, and Thailand.

8 Two of the claims were consequential claims raised separately under Article 1 of the ADA and Article 10 of the SCM Agreement. 


\subsection{Procedural issues}

Three claims were made by the US with regard to procedural aspects of the investigations. First, the US alleged that China acted inconsistently with Article 6.2 of the ADA because MOFCOM denied the US Government's request for a public hearing to present its views regarding the $\mathrm{AD}$ and $\mathrm{CVD}$ investigations in the presence of parties with adverse interests. Second, the US argued that China failed to meet its obligations under Articles 6.5.1 of the ADA and 12.4.1 of the SCM Agreement by failing to require the petitioner to provide adequate non-confidential summaries of certain data in the petition. Third, the US alleged that China failed to comply with Article 6.9 of the ADA by failing to make available 'essential facts', particularly the data and calculations used to determine the existence of dumping.

\subsubsection{Opportunity for a hearing with parties with adverse interests under Article} 6.2 of the ADA

The US alleged that China violated its obligation under Article 6.2 of the ADA by denying the US' request for a hearing with the parties with adverse interests in the $\mathrm{AD}$ and $\mathrm{CVD}$ investigations. Article 6.2 of the ADA provides that:

Throughout the anti-dumping investigation all interested parties shall have a full opportunity for the defence of their interests. To this end, the authorities shall, on request, provide opportunities for all interested parties to meet those parties with adverse interests, so that opposing views may be presented and rebuttal arguments offered. Provision of such opportunities must take account of the need to preserve confidentiality and any of the convenience to the parties. There shall be no obligation on any party to attend a meeting, and failure to do so shall not be prejudicial to that party's case. Interested parties shall also have the right, on justification, to present other information orally. [Emphasis added]

After the issuance of the preliminary determinations, the US sent a letter to MOFCOM on 12 July 2010 requesting a public hearing to present its views in the presence of parties with adverse interests on issues such as the definition of domestic industry, the lack of transparency in MOFCOM's conclusions, and the causation analyses as well as the price effects' analyses. In response, MOFCOM sent a letter dated 14 July 2010 to the US Government stating that, 'since the issues mentioned in the hearing request by the US Government are not relevant to the interested parties directly, the investigating authority decides to hear the US Government's opinions by a way of opinion presentation meeting. The opinion presentation meeting is expected to be held on July $20 .{ }^{9}$ The parties agreed that the so-called opinion presentation meeting take place on 20 July 2010 between MOFCOM and US Government officials without the presence of the petitioner or any other interested parties.

9 Panel Report, China-Broiler Products, para. 7.10, citing the MOFCOM Reply to the Hearing Request, Exhibit USA-24. 
China asserted that MOFCOM contacted the petitioner as well as other interested parties with adverse interests to the US Government by phone the day after receiving the hearing request. China claimed that MOFCOM extended invitations to those parties, but none of them was willing to attend the hearing. It further argued that the communications with the parties were sufficient to satisfy China's obligations under Article 6.2, especially in light of the fact that the opinion presentation meeting was offered and conducted, which allowed the US Government an opportunity to present its views since the parties with adverse interests would not have attended in any event. However, China was unable to provide any factual records to support its assertion except for its reply letter to the US Government.

In the Panel's view, the investigating authorities are charged with an obligation under Article 6.2 to provide opportunities for all interested parties to meet those with adverse interests so that views may be exchanged and rebuttal arguments offered, and the issue in this dispute was whether MOFCOM provided such an opportunity. ${ }^{10}$ The Panel stated that it had to conduct the review on the basis of the evidence on the record. Considering the lack of proof from China to support its claim, it concluded that MOFCOM failed to satisfy the requirements of Article 6.2 by not providing opportunities for interested parties with adverse interests to meet and exchange views. Therefore, the Panel held that China acted inconsistently with Article 6.2 of the ADA.

\subsubsection{Non-confidential summaries as required under Articles 6.5.1 of the ADA and 12.4.1 of the SCM Agreement}

The US claimed that MOFCOM failed to require the petitioner to provide adequate non-confidential summaries of information in the AD and CVD investigations with respect to six specific issues: (1) production and standing, (2) production capacity, (3) domestic inventory levels, (4) cash flow, (5) wages and employment, and (6) labor productivity.

Articles 6.5.1 of the ADA and 12.4.1 of the SCM Agreement provide that:

The authorities shall require [interested Members or] interested parties providing confidential information to furnish non-confidential summaries thereof. These summaries shall be in sufficient detail to permit a reasonable understanding of the substance of the information submitted in confidence. In exceptional circumstances, such [Members or] parties may indicate that such information is not susceptible of summary. In such exceptional circumstances, a statement of the reasons why summarization is not possible must be provided.

In the non-confidential version of the petition submitted by the CAAA to MOFCOM, certain information, including the issues identified by the US, was redacted and noted with the statement that: 'Confidentiality is applied as the trade secrets of the petitioner are involved if disclosing relevant data, which may 
have seriously adverse effect on the petitioner.'11 The US argued that the non-confidential summaries failed to meet the requirements of Articles 6.5.1 and 12.4.1, and in particular entailed the type of 'guess-work' which the Panel in China-GOES ${ }^{12}$ had found to be inconsistent with the requirements. China, on the other hand, maintained the position that the information provided was sufficient for the interested parties to gain a reasonable understanding of the redacted information. Moreover, China argued that the non-confidential summaries were later supplemented by the non-confidential analyses from MOFCOM provided in the preliminary and final AD and CVD determinations.

When evaluating the claim, the Panel stated that the issue was whether MOFCOM required the petitioner to provide non-confidential summaries of the confidential information redacted from the petition in accordance with Articles 6.5.1 and 12.4.1. To the Panel, the standard by which to assess the non-confidential summaries was quite clear, as the Appellate Body in EC-Fasteners (China) ${ }^{13}$ had provided that, "the sufficiency of the summary will depend on the confidential information at issue, the summary must permit a reasonable understanding of the substance of the information withheld, and allow the other parties to the investigation a meaningful opportunity to respond and defend their interests' ${ }^{14}$

With regard to China's argument that the non-confidential summaries were remedied by MOFCOM's analyses, the Panel held that the existing Panel findings have made it clear that Articles 6.5.1 and 12.4.1 do not provide for non-confidential summaries to be provided by the investigating authority, ${ }^{15}$ and therefore the investigating authority cannot make up the deficiencies in the non-confidential summaries from the interested party with its own summaries or analyses.

The Panel then proceeded to evaluate each of the six deficiencies in the non-confidential summaries identified by the US. A short summary of the Panel's findings with respect to the six specific areas is provided below.

Non-confidential summaries on production and standing. With respect to the production and standing information in the petition, the non-confidential version given presented a table which showed the figures for gross yield in China in the relevant years but deleted the data concerning the petitioner's production yield as well as their gross yield shares during those years. Supporting exhibits on production

11 Ibid., at para. 7.29 .

12 China - Countervailing and Anti-dumping Duties on Grain Oriented Flat-rolled Electrical Steel from the United States, Panel Report, WT/DS414/R, adopted 16 November 2012, upheld by the Appellate Body Report, WT/DS414/AB/R.

13 European Communities - Definitive Anti-dumping Measures on Certain Iron or Steel Fasteners from China, Panel Report, WT/DS397/R, adopted 28 July 2011, modified by the Appellate Body Report, WT/DS397/AB/R.

14 Panel Report, China-Broiler Products, para. 7.50, citing to Appellate Body Report, EC-Fasteners (China), paras. 541-542.

15 Panel Report, China-Broiler Products, para. 7.53. 
yield were listed as confidential and were not provided. Instead, a statement was given in the non-confidential version explaining that 'the yield represented by the Petitioner accounted for more than $50 \%$ of the gross yield during each of the reported years, and consequently, that the Petitioner has the right to submit the Petition on behalf of the broiler chicken industry of China'. ${ }^{16}$

In its review, the Panel found that most of the redacted information was relevant to the determinations made, such as the production yields to trends in capacity utilization for the injury determination. Stating that compliance with Articles 6.5.1 and 12.4.1 has to be assessed on the basis of 'whether the non-confidential version of the Petition enabled interested parties to understand the substance of the redacted information, rather than whether the non-confidential version permitted the interested parties to understand that the Petitioner was asserting that it had standing under Article 5.4' ${ }^{17}$ the Panel held that the absence of meaningful non-confidential summaries of the redacted information led to the conclusion that MOFCOM did not require the petitioner to provide non-confidential summaries consistent with Articles 6.5 .1 and 12.4 .1 on production and standing. ${ }^{18}$

Non-confidential summaries on production capacity. Regarding the information on production capacity, the non-confidential version of the petition provided tables for the relevant years but without the yearly figures concerning production capacity, yield, and capacity utilization, as well as graphs with only lines but no figures. According to China, the minimum and maximum production capacity figures could have been deduced by considering the petitioner's statement that it represented more than $50 \%$ of the total production in China, and with the estimates on utilization provided in the petition.

Similar to the evaluation for the production and standing, the Panel found that the graphs with no figures and with unmarked scale lines provided insufficient non-confidential summaries. As for the partial estimates that could be constructed by piecing together information from different parts of the petition and applying it to the graphs, the Panel determined that it did not provide a complete understanding of the redacted information and Articles 6.5.1 and 12.4.1 do not include an obligation requiring interested parties to derive and piece together their own summary of the redacted information. Under these Articles, the burden to provide adequate non-confidential summaries is for the party making the submission alone. ${ }^{19}$ In conclusion, the Panel considered that MOFCOM failed to require the petitioner to provide non-confidential summaries consistent with Articles 6.5.1 and 12.4.1 with respect to the information on production capacity. 
Non-confidential summaries on inventories, wages and employment, cash flow, and labor productivity. The Panel presented its evaluation on the non-confidential summaries for inventories, wages and employment, cash flow, and labor productivity together, because they shared a similar pattern. Tables, graphs, and explanations $^{20}$ were provided for each of these indicators, but the yearly amounts and year-on-year changes were redacted from the tables and the graphs were missing scales. In terms of specific data, only year-on-year changes in percentage terms were provided.

The Panel concluded that the non-confidential information provided did not permit a reasonable understanding of the substance of the redacted information because the available data did not allow for comprehension of the magnitude of the changes over the years. ${ }^{21}$ In short, without the baseline information for the tables or graphs, one could not have grasped an understanding of how inventories, wages and employment, cash flow, and labor productivity had changed over time. Thus, the Panel concluded that MOFCOM did not require the petitioner to provide non-confidential summaries consistent with Articles 6.5.1 and 12.4.1 with respect to the information on inventories, wages and employment, cash flow, and labor productivity.

Based on the findings for the six issues identified by the US, the Panel concluded that China failed to satisfy its obligations within the meaning of Articles 6.5.1 and 12.4.1 by not requiring the petitioner to provide non-confidential summaries of the information that was submitted in confidence.

\subsubsection{Disclosure of 'essential facts' as required by Article 6.9 of the ADA}

In its third procedural claim, the US alleged that China failed to disclose the 'essential facts' forming the basis of MOFCOM's decision to apply $\mathrm{AD}$ duties as required by Article 6.9 of the ADA, which provides:

The authorities shall, before a final determination is made, inform all interested parties of the essential facts under consideration which form the basis of the decision whether to apply definitive measures. Such disclosure should take place in sufficient time for the parties to defend their interests.

In the final $\mathrm{AD}$ disclosures for each mandatory respondent, i.e., Pilgrim's Pride, Tyson, and Keystone, MOFCOM provided a narrative description of the determinations of normal value and export price as well as the adjustments made thereto. Also, a table with company-specific figures relating to export volumes, export prices, normal values for the various product categories, and a total dumping margin for the subject merchandise as a whole was provided.

In the US' view, the 'essential facts' under Article 6.9 include both the calculations and the data relied upon by the investigating authority, and it argued that

20 Graphs and written explanations were provided for each of the four indicators except for labor productivity.

21 Panel Report, China-Broiler Products, para. 7.63-7.64. 
they all should have been disclosed by MOFCOM. According to the US, the required information to be disclosed included but was not limited to:

(i) all calculations performed with respect to the derivation of the normal value; (ii) all calculations performed with respect to the derivation of the export price; and (iii) all calculations performed with respect to the determination of costs of production. ${ }^{22}$

Additionally, the US claimed that detailed analyses of the data from each respondent, adjustments, and revisions made by MOFCOM to the sales data, the elimination or rejection of data by MOFCOM, as well as the actual files and spreadsheets created by MOFCOM should also have been disclosed. China mainly argued that the US' definition of 'essential facts' in this dispute was overly broad and that MOFCOM had provided all the facts necessary for the interested parties to defend their interests because 'one can trace the references made in the final disclosure documents to the specific adjustments and data contained in submission made by the respondents in the case' ${ }^{23}$

As the first step in the evaluation process, the Panel assessed what constitutes 'essential facts' and in interpreting this term, it referred to the reasoning set forth by the Appellate Body in China-GOES and the Panel in EC-Salmon (Norway) ${ }^{24}$ to hold that:

What constitutes 'essential facts' must therefore be understood in the light of the content of the findings needed to satisfy the substantive obligations with respect to the application of definitive measures under the Anti-dumping Agreement and SCM Agreement, as well as the factual circumstances of each case. These findings each rest on an analysis of various elements that an authority is required to examine...

... However, in our view, 'essential facts' are not simply the disclosure that a determination has been made, but rather the data that are the basis of the determination. Therefore, a declaration of the weighted-average dumping margin for a particular model will not suffice as a disclosure of essential facts under Article 6.9 without being accompanied by the data relied upon to reach that conclusion. ${ }^{25}$ [Emphasis added]

Therefore, according to the Panel the 'essential facts' which must be disclosed in the context of the determination of dumping include the underlying data for the following which form the basis for the dumping margin calculation:

elements that ultimately comprise normal value (including the price in the ordinary course of trade of individual sales of the like product in the home market or, in the case of constructed normal value, the components that make up the total cost of production, selling and general expenses, and profit); export price (including

22 Ibid., at para. 7.70.

23 Ibid., at para. 7.77.

24 European Communities- Anti-dumping Measure on Farmed Salmon from Norway, WT/DS337/R, adopted 15 January 2008.

25 Panel Report, China-Broiler Products, paras. 7.89-7.90. 
any information used to construct export price under Article 2.3); the sales that were used in the comparisons between normal value and export price; and any adjustments for differences which affect price comparability. ${ }^{26}$

In addition, the Panel considered that the domestic market and export sales used for the comparison and the formula applied for the comparison of the two would also have to be disclosed, because the formula applied is an essential element in the price comparison and enables interested parties to understand the dumping margin calculation and comment on the completeness as well as correctness of the conclusions drawn by the investigating authority. ${ }^{27}$

In particular, the Panel commented on the Panel ruling on a similar claim from the European Union in the dispute China-X-Ray Equipment, ${ }^{28}$ in which the latter Panel did not consider the 'actual mathematical determination' used by the investigating authority to calculate a respondent's dumping margin to be a 'fact ... under consideration', but held the mathematical determination to be a part of the 'consideration' of those facts. ${ }^{29}$ Since it was not clear whether the Panel in China-X-Ray Equipment meant for the words 'actual mathematic determination' to indicate the calculations themselves or the formula used to make the calculations, the Panel in this dispute stated that it agreed with the Panel in China-X-Ray Equipment to the extent that the calculations themselves, including the actual files and/or spreadsheets created by the investigating authority, are not 'essential facts' and did not have to be disclosed; but would disagree with the Panel in China-X-Ray Equipment if it meant that the formula for the calculations did not have to be disclosed. ${ }^{30}$

In summary, the Panel held that, pursuant to Article 6.9 of the ADA, the investigating authority must disclose what data were used in:

(i) the determination of normal value (including constructed normal value); (ii) the determination of export price; (iii) the sales that were used in the comparisons between normal value and export price; (iv) any adjustments for difference which affect price comparability; and (v) the formulas that were applied to the data. ${ }^{31}$

As the next step, the Panel proceeded to examine the facts in order to determine whether MOFCOM disclosed the 'essential facts' to the respondents. Specifically, the question was whether the three disclosures provided to the respondents contained the necessary level of detail as to the data used in the calculations to satisfy the obligations set forth by Article 6.9.

Each of the three disclosures, i.e., those of Pilgrim's Pride, Tyson, and Keystone, was reviewed and discussed in turn by the Panel. With respect to the disclosure to

26 Ibid., at para. 7.91.

27 Ibid.

28 China - Definitive Anti-dumping Duties on X-Ray Security Inspection Equipment from the European Union, WT/DS425/R, adopted 24 April 2013.

29 Panel Report, China-Broiler Products, para. 7.92.

30 Ibid., at para. 7.92 .

31 Ibid., at para. 7.93 . 
Pilgrim's Pride, the Panel found that MOFCOM failed to disclose the formula used for the sales below-cost test and formulas used to calculate normal value, export price, the dumping margins for each model, and the final total weighted-average dumping margin. ${ }^{32}$ Moreover, MOFCOM had mentioned in the final disclosure to Pilgrim's Pride that the company had made partial formula setup mistakes, which MOFCOM had fixed before conducting the sales below-cost test. However, it did not disclose the mistakes or how they were fixed. The Panel considered the missing information and formulas essential to the understanding of the construction of normal value, and given the other deficiencies found in the disclosure, it held that MOFCOM failed to disclose all the 'essential facts' underlying the determination of the existence of dumping to Pilgrim's Pride under Article 6.9.

For the disclosure to Tyson, the Panel found that MOFCOM should have disclosed the sales under consideration, the normal value of those sales used to calculate the aggregate normal value as well as the formulas used to calculate normal value, export price, and the weighted-average dumping margin. ${ }^{33}$

Similar to Pilgrim's Pride and Tyson, the formulas used to calculate normal value, export price, the dumping margins for each model, or the final total weighted-average dumping margin, and sales used to calculate normal value were absent from the disclosure to Keystone. But unlike the other two, Keystone had submitted certain cost data according to normal bookkeeping records and two alternative versions of costs with different weight-based methodologies after the release of the preliminary determination. In the final disclosure, although MOFCOM indicated that no factual changes had been made between the preliminary and final determinations, the AD duty rate had in fact changed from $44.0 \%$ in the preliminary determination to $53.35 \%$ in the final determination for Keystone. 34

On the basis of the findings for the three companies, the Panel held that China acted inconsistently with Article 6.9 of the ADA as MOFCOM did not disclose all the 'essential facts'.

\subsection{Substantive issues}

Besides the three procedural issues discussed above, nine other issues were examined by the Panel concerning the substantive determinations made by MOFCOM. ${ }^{35}$ In this section, we summarize the Panel's reasoning and findings with respect to the

32 Panel Report, China-Broiler Products, paras. 7.97-7.100.

33 Ibid., at paras. 7.101-7.104.

34 MOFCOM did indicate in the final disclosure that an adjustment was made to raw material prices and adjustments were also made to the export price with respect to the alleged errors in the reporting of freezer expenses. Panel Report, China-Broiler Products, para. 7.105.

35 The two consequential claims raised by the US under Article 1 of the ADA and Article 10 of the SCM Agreement are counted in the 14 total alleged violations but were not included as procedural or substantive issues in this paper. 
AD determinations, the CVD determinations, and the injury determinations in the $\mathrm{AD}$ and CVD investigations.

\subsubsection{Substantive issues with respect to the AD determinations}

Three issues were raised by the US concerning the AD determinations and they are discussed below.

Compliance with Article 2.2.1.1 of the ADA regarding the production cost calculation. The US argued that China acted inconsistently with Article 2.2.1.1 of the ADA by: rejecting without any consideration and explanation the costs in the respondents' normal books and records, and especially their cost allocations, in constructing the normal value, even though the records were consistent with the generally accepted accounting principles (GAAP) and reasonably reflected the costs associated with the production and sales of the product under consideration; applying a cost allocation methodology that was itself inconsistent with Article 2.2.1.1 as it did not reasonably reflect the costs associated with the production and sales of the product under consideration; and including in the allocation methodology for one company (Tyson) costs for products not subject to the investigation. In response, China maintained that it was 'perfectly proper' for it to decline the use of costs in the records of the respondents because they 'did not reasonably reflect the costs associated with the production and sale of the product under consideration'. ${ }^{36}$ Moreover, China considered that its own cost allocation methodology was in line with the requirements of Article 2.2.1.1 and it did not allocate costs for the non-subject product.

Article 2.2.1.1 provides that for the construction of the normal value on the basis of the cost of production in the country of origin plus a reasonable amount for administrative, selling, and general costs, and for profits within the meaning of Article 2.2:

costs shall normally be calculated on the basis of records kept by the exporter or producer under investigation, provided that such records are in accordance with the generally accepted accounting principles of the exporting country and reasonably reflect the costs associated with the production and sale of the product under consideration. Authorities shall consider all available evidence on the proper allocation of costs, including that which is made available by the exporter or producer in the course of the investigation ... Unless already reflected in the cost allocations under this subparagraph, costs shall be adjusted appropriately for those non-recurring items of cost which benefit future and/or current production, or for circumstances in which costs during the period of investigation are affected by start-up operations. [Footnote omitted; emphasis added]

36 Panel Report, China-Broiler Products, para. 7.109. 
The Panel began its assessment by evaluating whether there is an obligation for an investigating authority to explain its decision to decline to use a respondent's books and records. In this context, interpreting Article 2.2.1.1, the Panel referred to the explanations given by the Panel in US-Softwood Lumber $V,{ }^{37}$ that an investigating authority is obliged to use the records kept by the respondents as long as two conditions are met: first, the records are consistent with the GAAP of the exporting country; and, second, they reasonably reflect the costs associated with the production and sales of the product under consideration. ${ }^{38}$ More specifically, in analyzing the use of the term 'normally' in Article 2.2.1.1, the Panel came to the conclusion that 'an investigating authority is bound to explain why it departed from the norm and declined to use a respondent's books and records'. ${ }^{39}$

Therefore, the Panel was of the view that the investigating authority retains the right to decline the use of costs in the books and records kept by the respondent if it determines that they are either inconsistent with the GAAP of the exporting country or do not reasonably reflect the costs associated with the product and sale of the product under investigation, but when making a determination to derogate from the norm the authority must set forth its reasons for doing so. ${ }^{40}$ China attempted to argue that the passive voice of Article 2.2.1.1 indicates that there is no positive obligation for the investigating authority to explain its reasons for declining to use the books and records of the respondent, and the burden was on the submitting party to demonstrate that it had met the two criteria. ${ }^{41}$ The Panel did not make a finding on who bears the initial burden of proof, but stated that the obligation on the investigating authority to explain its decision is not excused either way. It held that, '[i]f that decision results from an affirmative determination to reject the books or if it is because the respondent did not prove that its books satisfy the two criteria, those reasons must be set forth in the record of the investigation and/or the published determinations, so as to allow for review of that decision'. ${ }^{42}$

The Panel then turned to examine whether MOFCOM correctly determined that the respondents' books and records did not reasonably reflect the costs associated with the production and sale of the product under consideration. First, it established that the consistency with the GAAP itself, i.e., US GAAP in the present dispute, was not proof that the records also reasonably reflected a company's costs. ${ }^{43}$ In other words, the two criteria are different and satisfying one requirement does not mean automatic fulfillment of the other.

37 United States - Final Dumping Determination on Softwood Lumber from Canada, Panel Report, WT/DS/264/R, adopted 1 September 2006, reversed by the Appellate Body Report, WT/DS264/AB/R.

38 Panel Report, China-Broiler Products, para. 7.160.

39 Ibid., at para. 7.161.

40 Ibid., at para. 7.164 .

41 Ibid., at para. 7.163 .

42 Ibid., footnotes omitted.

43 Panel Report, China-Broiler Products, para. 7.166. 
Second, the Panel reviewed China's arguments in justifying its conclusion that the respondents' books and records did not reasonably reflect the costs associated with the production and sale of the product under consideration. China explained before the Panel that the respondents provided incorrect values to determine the proportion of pre-split-off costs to allocate to each product and that the cost allocation methods of the respondents were not reasonable, e.g., treating chicken paws as by-products rather than as a main joint product. ${ }^{44}$ The Panel found that such justifications could serve as a basis for determining that the books and records of Tyson and Keystone did not reasonably reflect the production costs of chicken paws under Article 2.2.1.1, but based on the record of the investigation the Panel held that it could not conclude that these were the reasons for rejecting the costs of these companies, and MOFCOM had failed to provide the supporting reasoning for its conclusion in the preliminary and final determinations. ${ }^{45}$

With respect to Pilgrim's Pride, the Panel determined that MOFCOM did provide reasons for rejecting its books and records in the preliminary and final determinations and in the disclosure documents by pointing out that the company's records were incomplete and the data were irreconcilable and not corrected in a timely manner. ${ }^{46}$ Therefore, the Panel considered that the US had not established that China acted inconsistently with the first sentence of Article 2.2.1.1 with regard to Pilgrim's Pride.

The Panel subsequently evaluated the issue whether MOFCOM complied with the requirement in the second sentence of Article 2.2.1.1 - notably to consider all available evidence to arrive at the proper allocation of costs - when it formulated and applied its own cost allocation methodology in constructing the normal value. According to the Panel, it had to address three questions: '(i) whether MOFCOM did more than simply receive evidence and take note of evidence; (ii) whether, in this particular instance, MOFCOM was required to reflect on and weigh the merits of the various allocation methodologies; and (iii) if so, whether there was evidence of its consideration reflected in relevant documentation'. ${ }^{47}$ The Panel additionally noted that it had also to decide whether the methodology used by MOFCOM was 'proper'.

In addressing the first question, the Panel found that not only had MOFCOM received evidence from the respondents, i.e., books and records and proposal/s of cost methodologies, it had also asked a number of questions to the respondents in the questionnaires about the cost allocation methods filed by them. For the

44 Ibid., at para. 7.169, including footnote 294.

45 Ibid., at para. 7.171 .

46 Ibid., at paras. 7.173-7.174. MOFCOM's treatment for Pilgrim's Pride was remarkably different from those of Tyson and Keystone. The other two simply received a one-line conclusion that their costs were unreasonable without any explanation, but MOFCOM explained in detail that it rejected Pilgrim's Pride's data as they were incomplete and the efforts to correct them were untimely.

47 Panel Report, China-Broiler Products, para. 7.192. 
second question, taking into account that the Appellate Body in US-Softwood Lumber V clearly ruled that, in instances where there is "compelling evidence" available to the investigating authority that more than one allocation methodology potential may be appropriate to ensure that there is a proper allocation of costs, the investigating authority may be required to "reflect on" and "weigh the merits of" evidence that relates to such alternative allocation methodologies, in order to satisfy the requirement to "consider all available evidence", 48 the Panel held that MOFCOM was required to 'reflect on and weigh the merits of the various allocation methodologies'. Regarding the third question, the Panel noted that China did not provide any evidence from the record of the investigation demonstrating that MOFCOM had deliberated or explained its methodology or why it chose to apply the particular cost allocation methodology over the other proposed ones. ${ }^{49}$ Thus, the Panel determined that China acted inconsistently with the second sentence of Article 2.2.1.1 for failing to consider 'all available evidence' for the proper allocation of costs."

Finally as to whether MOFCOM's cost allocation methodology was 'proper' allocation of costs, the Panel concluded that it was not, and the methodology used by MOFCOM was inconsistent with Article 2.2.1.1 because the straight allocation of total processing costs to all products implied 'that it included costs solely associated with processing certain products in its calculation of costs to all subject broiler products' ${ }^{50}$ In addition, the Panel determined that MOFCOM improperly allocated costs of non-subject products to subject products in the calculation of the normal value for Tyson. ${ }^{51}$

In summary, the Panel held that China also acted inconsistently with the second sentence of Article 2.2.1.1 as there was insufficient evidence that MOFCOM considered 'all available evidence' presented by the respondents on the alternative allocation methodologies, improperly allocated all processing costs to all products, and incorrectly allocated the costs of non-subject products in the construction of the normal value.

Compliance with Article 2.4 of the ADA regarding the comparison between normal value and export price. The US claimed that MOFCOM violated with

48 Ibid.

49 Ibid., at para. 7.194.

50 As the Panel stated in footnote 338, some products have higher processing costs than others, e.g., the processing of breast meat involves procedures such as skinning, deboning, and deveining, which are more labor-intensive and costly than the production of other chicken parts. Panel Report, China-Broiler Products, para. 7.196.

51 Panel Report, China-Broiler Products, para. 7.197. China argued that it used Tyson's own data and submitted a table (Exhibit CHN-64) that summarized the data provided by Tyson. Upon examination, the Panel found that the non-subject products were not listed in the breakdown, so that the table did not show that the costs assigned to individual products excluded the costs of non-subject products from the total cost. It concluded that the US made a prima facie case based on the evidence. 
Article 2.4 of the ADA by deducting the freezer storage expenses from the export price of Keystone. According to the US, the adjustment was unwarranted. The US further argued that even if it was warranted, it led to an imbalance between the export price and normal value as the latter was constructed using production costs that included freezer storage expenses and thus MOFCOM failed to conduct a fair comparison between the normal value and the export price. China disputed the US' arguments by first arguing that the claim was not included in the US' request for consultations, but only asserted later in the Panel request, and therefore it fell outside the terms of reference of the Panel, and second by submitting that the adjustment was consistent with the requirement of Article 2.4.

With respect to China's objection to the Panel's consideration of a claim that was not included in the consultations' request but only in the Panel request, the Panel stated that a number of Panels and the Appellate Body have examined the question in prior disputes. The Panel agreed with the reasoning of the Appellate Body in Mexico-Anti-Dumping Measures on Rice that 'it is not necessary that the provisions referred to in the request for consultations be identical to those set out in the Panel request, provided that the "legal basis" in the Panel request may reasonably be said to have evolved from the "legal basis" that formed the subject of consultations; the addition of provisions must not have the effect of changing the essence of the complaint'. ${ }^{52}$ On this basis, the Panel reasoned that there must be some connection between the claims provided in the Panel request and those identified in the consultations request for the claim to be considered, which required a comparison of the relevant parts of the claims in the two documents. ${ }^{53}$

Different from the US' Panel request, which was on point and with details for the present claim under Article 2.4, the consultations request was very concise and contained only two claims, one challenging the specific determination of the normal value by MOFCOM under Articles 2.2 and 2.2.1.1 of the ADA, and the other alleging MOFCOM's failure to make proper cost allocations under Article 2.2.1.1. ${ }^{54}$ Based on the comparison, the Panel concluded that neither of the claims in the consultations request could have reasonably evolved into the Article 2.4 claim included in the Panel request, and any connection between the issues set forth in

52 Panel Report, China-Broiler Products, para. 7.222, citing to Appellate Body Report, Mexico Definitive Anti-Dumping Measures on Beef and Rice, Complaint with Respect to Rice, WT/DS295/AB/ R, adopted 20 December 2005, para. 138; also citing to Panel Report, Canada-Measures Affecting the Export of Civilian Aircraft, WT/DS70/R, adopted 20 August 1999, para. 91.2, upheld by the Appellate Body Report, WT/DS70/AB/R; Appellate Body Report, India-Patent Protection for Pharmaceutical and Agricultural Chemical Products, WT/DS50/AB/R, adopted 16 January 1998, para. 94; Appellate Body Report, Brazil-Export Financing Programme for Aircraft, WT/DS46/DS/R, adopted 20 August 1999, para. 132; Appellate Body Report, United States-Subsidies on Upland Cotton, WT/DS267/AB/R, adopted 21 March 2005, para. 293.

53 Panel Report, China-Broiler Products, paras. 7.224-7.225.

54 Ibid., at paras. 7.226-7.229. 
the consultations request and the Panel request was 'tenuous at best'. ${ }^{55}$ Therefore, it held that the US' claim under Article 2.4 of the ADA fell outside of the Panel's term of reference and the merits of the claim were therefore not considered.

The calculation of the 'all others' rate for unknown producers/exporters in the AD investigation. With regard to the 'all others' rate determined by MOFCOM in the AD investigation, the US raised three issues under the claim.

\section{Article 6.8 and Annex II, paragraph 1, of the ADA}

The US argued that China acted inconsistently with Article 6.8 and Annex II, paragraph 1, of the ADA because 'all other' producers/exporters were not notified of the initiation of the investigation, the information required of them and that the failure to participate and provide the relevant information would result in a determination based on facts available to them. As a result, the failure of these parties to register did not justify the application of facts available. Moreover, the US argued that MOFCOM applied 'facts available' in a manner that was in violation of Article 6.8, because the 'all others' rate was more than twice as high as any of the individual margins or the rate for the companies that registered but were not individually investigated, it was 'apparently adverse' to the interests of those producers/exporters, ${ }^{56}$ and also because MOFCOM did not explain how it arrived at that rate.

Article 6.8 provides that:

In cases in which any interested party refuses access to, or otherwise does not provide necessary information within a reasonable period or significantly impedes the investigation, preliminary and final determinations, affirmative or negative, may be made on the basis of the facts available. The provisions of Annex II shall be observed in the application of this paragraph.

The Panel recalled that Article 6.8 permits the resort to facts available in certain circumstances and provided that as required by paragraph 1 of Annex II, the investigating authority has 'specified in detail the information required' and 'ensured that the party is aware that if information is not supplied within reasonable time, it may resort to "facts available"". 57 The Panel further stated that Article VI of the GATT 1994 and the ADA permit the imposition of duties on all imports that are found to have been dumped and to have caused injury, and on exports from producers/ exporters that did not exist or export during the period of investigation (POI). ${ }^{58}$ In the present case, MOFCOM took the following steps to inform the interested parties of the relevant information in the $\mathrm{AD}$ investigation: (i) it issued a Notice

55 Ibid., at paras. 7.230-7.231.

56 The 'all others' rate was $105.4 \%$ in both the preliminary and final determinations.

57 Panel Report, China-Broiler Products, para. 7.301.

58 Ibid., at para. 7.302 . 
of Initiation (NoI) on its website along with the registration form; (ii) it placed the NoI in the public reading room at MOFCOM; (iii) it also sent the NoI to the US Embassy in China. ${ }^{59}$ The US argued that these actions taken by MOFCOM were not sufficient to notify the interested parties based on the ruling by the Appellate Body in Mexico-Anti-Dumping Measures on Rice. ${ }^{60}$

The Panel rejected the US' line of reasoning and stated that the Appellate Body in Mexico-Anti-Dumping Measures on Rice was addressing a very specific and factually different situation than the one at hand and it did not read that finding as establishing a general rule that in all circumstances a request for information must be conveyed through an individualized communication. ${ }^{61}$ The Panel also found it difficult to accept the US' arguments on the ground that it would make it difficult for members to determine an appropriate AD duty for the unknown producers/exporters and to apply AD measures on their imports. The Panel considered that it could create an incentive for producers/exporters not to cooperate with the investigation, since they would benefit from non-cooperation in terms of no AD duty on their products. ${ }^{62}$

Based on the foregoing, and in light of the reasonableness of the communication methods adopted by MOFCOM to inform the interested parties in the investigation, the Panel considered that MOFCOM fulfilled its obligations under Article 6.8 and paragraph 1 of Annex II in order to resort to 'facts available' for the calculation of the 'all others' rate. ${ }^{63}$

Having determined the first aspect of the US' claim, the Panel turned to evaluate the second matter raised by the US, namely, whether MOFCOM's determination of the 'all others' rate was consistent with Article 6.8. The Panel noted that the Appellate Body in Mexico-Anti-Dumping Measures on Rice established that the use of 'facts available' to replace the absent information is not unlimited, and that the Panel in China-GOES, in examining Article 12.7 of the SCM Agreement, held in particular that determinations reached on the basis of 'facts available' cannot be 'devoid of any factual foundation'. ${ }^{64}$ The Panel considered that 'the rate based on facts available must have a logical relationship with the facts on the record and be a result of an evaluative, comparative assessment of those facts'. ${ }^{65}$ It held that the limited explanations provided by MOFCOM on the calculation of the 'all others' rate precluded an understanding of the facts on the record used to calculate that rate. The Panel therefore ruled that China acted inconsistently with Article 6.8 in the calculation of the 'all others' rate.

59 Ibid., at para. 7.300.

60 Ibid., at para. 7.304.

61 Ibid.

62 Ibid.

63 Ibid., at paras. 7.306-7.307.

64 Panel Report, China-Broiler Products, paras. 7.310-7.312, footnotes omitted, citing to the Panel Report, China-GOES, para. 7.302.

65 Panel Report, China-Broiler Products, para. 7.312. 


\section{Article 6.9 of the ADA}

The second issue concerning the 'all others' rate brought by the US was that China acted inconsistently with Article 6.9 of the ADA by failing to disclose the 'essential facts under consideration' with regard to the 'all others' rate.

Having recalled its discussion on the issue of 'essential facts' under Article 6.9 with respect to MOFCOM's decision to impose AD duties, ${ }^{66}$ the Panel considered that the essential facts that MOFCOM was required to disclose in the present context included the basis for its decision to resort to 'facts available', the information requested from interested parties, and the facts that were used to replace the missing information. ${ }^{67}$ Essentially, the Panel considered that the investigating authority is under an obligation to disclose the actual data underlying its decision. The Panel found that MOFCOM did not disclose the 'essential facts under consideration' to the interested parties as the disclosure documents only gave a conclusory statement on the 'all others' rate and not the data that were used to replace the missing information. ${ }^{68}$ Therefore, the Panel concluded that China acted inconsistently with Article 6.9 for failing to disclose the 'essential facts' forming the basis of the determination of the 'all others' rate.

\section{Public notice requirements in Articles 12.2, 12.2, and 12.2.2 of the ADA}

For the third issue regarding the 'all others' rate in the AD determinations, the US claimed that China acted inconsistently with the requirements of Article 12.2, 12.2.1 and 12.2.2 of the ADA by not explaining in sufficient detail the findings and conclusions leading to the application of 'facts available', by not providing 'a full explanation of the methodology used to establish the export price and normal value used for 'all other' respondents, or all relevant information underlying its determination'. ${ }^{69}$ China claimed that it had provided the required information under the concerned articles.

The Panel chose not to consider the claim under Article 12.2.1 because it concerned the public notice of the preliminary measures, and the Panel decided to only make findings with respect to MOFCOM's final AD determination, reasoning that the language of the preliminary and final determinations was not substantively different and a finding with respect to the preliminary determination would not help secure a positive solution to the dispute. ${ }^{70}$

Article 12.2 requires the investigating authority to provide public notice:

of any preliminary or final determination, whether affirmative or negative, of any decision to accept an undertaking pursuant to Article 8, of the termination of such

66 We note that the text of Article 6.9 of the ADA has been provided in Section 3.1.3 of this paper. 67 Panel Report, China-Broiler Products, paras. 7.316-7.317.

68 Ibid., at paras. 7.318-7.319.

69 Ibid., at para. 7.324 .

70 Ibid., at para. 7.326 . 
an undertaking, and of the termination of a definitive anti-dumping duty. Each such notice shall set forth, or otherwise make available through a separate report, in sufficient detail the findings and conclusions reached on all issues of fact and law considered material by the investigating authorities. All such notices and reports shall be forwarded to the Member or Members the products of which are subject to such determination or undertaking and to other interested parties known to have an interest therein. [Emphasis added]

The obligation of Article 12.2 is further elaborated in Articles 12.2.1 and 12.2.2. Specifically, Article 12.2.2 provides that:

A public notice of conclusion or suspension of an investigation in the case off an affirmative determination providing for the imposition of a definitive duty or the acceptance of a price undertaking shall contain, or otherwise make available through a separate report, all relevant information on the matters of fact and law and reasons which have led to the imposition of final measures or the acceptance of a price undertaking, due regard being paid to the requirements for the protection of confidential information. [Emphasis added]

Based on the requirement in Article 12.2 that sufficient details of the 'findings and conclusions reached on all issues of fact and law considered material by the investigation authorities' be disclosed in the public notice or a separate report, and the Appellate Body ruling in China-GOES that the disclosure 'must allow an understanding of the factual basis that led to the imposition of final measures and give a reasoned account of the factual support for an authority's decision', ${ }^{71}$ the Panel evaluated MOFCOM's final determination and found that it failed to provide the 'findings and conclusions reached on all issues of fact and law considered material'. In particular, the Panel held that MOFCOM's determination did not explain the relevant factual matters leading to the conclusion that the 'all others' rate was the appropriate $\mathrm{AD}$ duty rate of all other producers/exporters. ${ }^{72}$ Consequently, the Panel held that China acted inconsistently with Articles 12.2 and 12.2.2.

\subsubsection{Substantive issues with respect to the CVD determinations}

The US made two claims with regard to the CVD determination, one of them in parallel with the 'all others' rate claim raised in the context of the $\mathrm{AD}$ determinations, and the other as a challenge under Article 19.4 of the SCM Agreement and Article VI:3 of the GATT 1994 regarding the proper allocation of the alleged subsidy.

71 Panel Report, China-Broiler Products, paras. 7.327-7.328, footnotes omitted, citing to the Appellate Body Report, China-GOES, para. 256.

72 Panel Report, China-Broiler Products, at para. 7.329. 
The calculation of the 'all others' rate for unknown producers/exporters in the CVD investigation. Almost identical to the claims raised with respect to the 'all others' rate in the AD investigation, three issues were brought by the US concerning MOFCOM's determination of the 'all others' rate in the CVD investigation. ${ }^{73}$ The challenged articles under the SCM Agreement corresponded for the most part to those identified under the ADA. In detail, the US claimed that (1) China acted inconsistently with Article 12.7 of the SCM Agreement by imposing an 'all others' rate on the basis of adverse facts available to producers/exporters that MOFCOM did not notify of the required information of them and did not refuse to provide the necessary information or otherwise impede the subsidy investigation; (2) China acted inconsistently with Article 12.8 of the SCM Agreement by failing to inform the US and other interested parties of the 'essential facts' that formed the basis of MOFCOM's calculation of the 'all others' rate; and (3) China acted inconsistently with Articles 22.3, 22.4 and 22.5 of the SCM Agreement on account of MOFCOM's failure to disclose in sufficient detail 'the findings and conclusion reached on all issues of fact, or all relevant information on matters of fact'. ${ }^{74}$

Because of the similarities between the CVD claims and the AD claims with respect to the 'all others' rates, the Panel found it appropriate to transpose its reasoning and conclusions concerning the parallel $\mathrm{AD}$ issues and make only brief analyses for the CVD issues. ${ }^{75}$ With respect to the issue under Article 12.7, the Panel noted that the three aspects of that claim largely mirrored the arguments brought by the US under Article 6.8 of the ADA, with the differences being that the SCM Agreement does not have an equivalent to Annex II of the ADA. ${ }^{76}$ Based on the reasons discussed above for the AD claim, the Panel found that MOFCOM could determine the 'all others' rate on the basis of facts available on the record of the investigation, but the 'all others' rate was not established consistently with Article 12.7 of the SCM Agreement because its discussion of the calculation of the 'all others' rate did not disclose which subsidy programs MOFCOM took into consideration and why. Furthermore, MOFCOM did not provide any reasons for choosing to apply a different methodology in calculating the benefit for the 'all others' rate than the one used for individually examined producers/ exporters. ${ }^{77}$ Therefore, the Panel found that the US had established a prima facie case of violation which had not been rebutted by China and held that China has acted inconsistently with Article 12.7 of the SCM Agreement with respect to the application of the 'all others' rate on the basis of facts available to US producers/ exporters who failed to register.

\footnotetext{
73 The 'all others' CVD rate is $30.3 \%$ in the final CVD determination.

74 Panel Report, China-Broiler Products, para. 7.332.

75 Ibid., at paras. 7.354-7.360.

76 Ibid.

77 Ibid., at para. 7.359 .
} 
Regarding the issue under Article 12.8 of the SCM Agreement concerning the obligation to disclose the 'essential facts under consideration' pertaining to the 'all others' rate in the CVD investigation, the Panel reached the same conclusion as it did with respect to the parallel issue in the $\mathrm{AD}$ investigation, stating that the obligations of Article 12.8 of the SCM Agreement are the same as those under Article 6.9 of the ADA and that MOFCOM's disclosure did not make clear the program/s and/or underlying data relied upon to determine the 'all others' rate. ${ }^{78}$ Consequently, the Panel held that China acted inconsistently with Article 12.8 of the SCM Agreement for failing to disclose certain 'essential facts' underlying its decision to apply the 'all others' CVD rate.

Last, concerning MOFCOM's failure to disclose the rationale and the relevant factual basis underlying MOFCOM's determination of the 'all others' rate, the Panel adhered to the reasoning adopted with respect to the parallel AD issue and found that MOFCOM acted contrary to the requirements of Articles 22.3 and 22.5 by not providing in sufficient detail the 'findings and conclusions reached on all issues of fact considered material, and all relevant information on the matters of fact'. ${ }^{79}$ Accordingly, the Panel determined that China acted inconsistently with Articles 22.3 and 22.5 of the SCM Agreement.

The per unit subsidization calculation as required by Article 19.4 of the SCM Agreement and Article VI:3 of the GATT 1994. In its second claim with respect to the CVD determinations, the US alleged that China acted inconsistently with Article 19.4 of the SCM Agreement and Article VI:3 of the GATT 1994 because MOFCOM erroneously included a subsidy that benefitted the production of non-subject products in the calculation of per unit subsidization for the product concerned for Pilgrim's Pride and Tyson. ${ }^{80}$ According to the US, the calculated CVDs were higher than the subsidies received by these two companies for the production of the subject merchandise, as the numerators of the subsidy equations contained a subsidy which benefitted the production of non-subject products while the denominators reflected only the sales volume of the subject products, thereby creating an asymmetry and leading to incorrect CVDs. ${ }^{81}$

Article 19.4 of the SCM Agreement states that:

No countervailing duty shall be levied on any imported product in excess of the amount of the subsidy found to exist, calculated in terms of subsidization per unit of the subsidized and exported product. [Footnotes omitted]

78 Ibid., at paras. 7.361-7.363.

79 Panel Report, China-Broiler Products, para. 7.366. Similar to the analysis for the AD claim regarding Articles 12.2, 12.2.1, and 12.2.2 of the ADA, the Panel did not consider it necessary to make a finding regarding the preliminary CVD determination. Thus, the alleged violation under Article 22.4 was not considered.

80 Panel Report, China-Broiler Products, para. 7.234.

81 Ibid. 
Under Article VI:3 of the GATT 1994:

No countervailing duty shall be levied on any product of the territory of any contracting party imported into the territory of another contracting party in excess of an amount equal to the estimated bounty or subsidy determined to have been granted, directly or indirectly, on the manufacture, production or export of such product in the country of origin or exportation, including any special subsidy to the transportation of a particular product.

The Panel noted that the parties agreed on the obligation imposed by Articles 19.4 of the SCM Agreement and Article VI:3 of the GATT 1994, which is that the investigating authority must 'accurately determine the per unit subsidy amount and not impose countervailing duties exceeding that amount' ${ }^{82}$ Consequently, the issue before the Panel was one of application and not of interpretation. More specifically, the Panel considered that the main issue was whether MOFCOM provided 'a reasoned and adequate explanation of how the facts support its determination that the reported data was appropriate to use in the per unit subsidy calculation'. ${ }^{83}$

The practical point of contention between China and the US on the issue was whether China incorrectly used the data for the amount of corn and soybean utilized in the production of subject imports for Pilgrim's Pride and Tyson in calculating a per unit subsidization rate. The two parties argued over the interpretation/ translations of certain specific questions in relation to the total quantities of soybean and corn in the second Supplementary Questionnaires to Pilgrim's Pride and Tyson. The former understood the questions to require the consumption in the production of subject imports, and the latter interpreted them as asking for the total consumption of soybeans and corn used in production of all products, both subject and non-subject products. ${ }^{84}$ The Panel did not make a finding on this issue because it could not be certain whether any of the translations presented to it were what the respondents relied upon when they actually prepared the data for the responses, and also because it considered it 'a distraction' from the main issue. $^{85}$ The Panel stated that, the obligation imposed by Articles 19.4 of the SCM Agreement and VI:3 of the GATT 1994 'requires more effort on the part of an investigating authority than simply accepting data and using it' ${ }^{86}$ Furthermore, it referred to the Appellate Body's holding in US-Wheat Gluten ${ }^{87}$ and considered that MOFCOM needed to ensure that it had calculated the correct subsidy amount, particularly in light of the fact that the respondents had

82 Ibid., at para. 7.258 .

83 Ibid., at para. 7.258.

84 Ibid., at para. 7.260.

85 Ibid., at paras. 7.260-7.261.

86 Ibid., at para. 7.261.

87 United States - Definitive Safeguard Measures on Imports of Wheat Gluten from the European Communities, Panel Report, WT/DS166/R, adopted 19 January 2001, modified by the Appellate Body Report, WT/DS166/AB/R. 
noted in their comments on the preliminary CVD determination that they may have misunderstood the question and provided incorrect data and the amount of subsidy that MOFCOM was allocating to the subject products might include subsidies to excluded products. ${ }^{88}$ The Panel determined that MOFCOM failed to properly address the arguments of the US, Pilgrim's Pride, and Tyson on this issue as it essentially maintained that it used the information received and its calculation contained no error.

According to the Panel, MOFCOM did not take sufficient account of the conflicting evidence and did not respond to the competing plausible explanations of that evidence to ensure that its calculation was correct nor did it provide a reasoned and adequate explanation as to why the facts supported the conclusions it reached with regard to the subsidy amount attributed to the imported products. Based on the foregoing, the Panel determined that China did not act consistently with Article 19.4 of the SCM Agreement and Article VI:3 of the GATT 1994 because MOFCOM failed to ensure that the CVD imposed was not in excess of the amount of the subsidization per unit of the subsidized and exported product.

\subsubsection{Substantive issues with respect to the injury determinations}

The US brought four separate claims to challenge MOFCOM's injury determinations regarding the following aspects: (1) MOFCOM's definition of the domestic industry; (2) MOFCOM's price undercutting and price suppression analyses in the final determinations; (3) MOFCOM's injury analyses in the final determinations; and (4) MOFCOM's causation analyses in the final determinations, all of which were raised under combinations of various provisions of the ADA and the SCM Agreement. We proceed to discuss each of these four claims in turn below.

The Definition of domestic industry for the purpose of the injury determination under Articles 3.1 and 4.1 of the ADA and Articles 15.1 and 16.1 of the SCM Agreement. The US questioned MOFCOM's definition of domestic industry under two sets of linked provisions. The US argued that MOFCOM's determination of what group of producers comprised the domestic industry was inconsistent with Articles 4.1 of the ADA and 16.1 of the SCM Agreement because it did not seek to define the domestic industry as a whole 'before turning to define the domestic industry as producers of a major proportion of the total domestic output of the like products', it did not make independent efforts to determine the extent of the domestic industry in particular by not investigating the possible existence of domestic producers other than those made known to it by the petitioner, and it limited the domestic industry to producers supporting the petition. With respect to Articles 3.1 of the ADA and 15.1 of the SCM Agreement, 
the US claimed that the improper exclusion of producers from the domestic industry resulted in an injury analysis that was not based on positive evidence or an objective examination of the effects of the imports on the domestic industry. ${ }^{89}$

The Panel assessed the US' claims as follows: first, it assessed whether Articles 4.1 of the ADA and 16.1 of the SCM Agreement obligate the investing authority to make an attempt to identify and seek information from all domestic producers; and, second, it evaluated whether MOFCOM's definition of the domestic industry involved a self-selection process which excluded producers from the domestic industry causing material risk of distortion in the injury analysis. ${ }^{90}$

The relevant part of Article 4.1 of the ADA provides that:

the term 'domestic industry' shall be interpreted as referring to the domestic producers as a whole of the like products or to those of them whose collective output of the products constitutes a major proportion of the total domestic production of those products. ${ }^{91}$ [Emphasis added]

The Panel first pointed out that the texts of Articles 4.1 and 16.1 do not provide clear instructions as to how the investigating authority should determine whether the domestic industry will consists of the domestic producers 'as a whole' or those whose output represents 'a major proportion of total domestic production'. In particular, it considered that the usage of the term 'or' indicates flexibility for the investigating authority in defining the domestic industry on the basis of one out of the two definitions, meaning that an investigating authority is not required to identify all domestic producers before defining the 'domestic industry' as consisting of those producers 'whose collective output of the products constitutes a major proportion of the total domestic production', although the latter must be determined in relation to the production of the domestic producers as a whole. ${ }^{92}$ The total domestic production has to be established first in order for the investigating authority to determine whether it can define the domestic industry as the domestic producers as a whole, or with reference to those producers that represent a major proportion of the total domestic production or conclude that it has no information on the domestic industry. According to the Panel, the investigating authority may use the information provided by the petitioner, 'particularly if it was gathered from independent sources'. 93 However, the investigating authority has to make

89 Ibid., at paras. $7.370-7.372$.

90 Ibid.

91 Article 16.1 of the SCM Agreement is substantially similar to Article 4.1 of the ADA. Articles 3.1 of the ADA and 15.1 of the SCM Agreement were not examined in-depth by the Panel for this issue. The text of these two articles are the same: 'A determination of injury for purpose of Article VI of GATT 1994 shall be based on positive evidence and involve an objective examination of both (a) the volume of the dumped [subsidized] imports and the effect of the dumped [subsidized] imports on prices in the domestic market for like products, and (b) the consequent impact of these imports on domestic producers of such products' [Footnotes omitted].

92 Panel Report, China-Broiler Products, paras. 7.416-7.419.

93 Ibid., at para. 7.422 . 
reasonable and practicable efforts for ensuring that the information it uses, whether from the petitioner or other sources, is accurate. Given the fact that the US had not made any contentions regarding MOFCOM's determination of the total domestic production or the responding producers constituting a major proportion, the Panel concluded that the US had not made a case that China acted inconsistently with Articles 3.1 and 4.1 of the ADA and Articles 15.1 and 16.1 of the SCM Agreement by not seeking to identify all domestic producers in the process of defining the domestic industry. ${ }^{94}$

In the context of the US' claim that MOFCOM's domestic industry defining process involved a self-selection process whereby producers supporting the complaint were more likely to be included in the domestic industry, the Panel considered that MOFCOM did not use sampling and did not exclude any of the information it received from the producers, whether registered or non-registered companies. ${ }^{95}$ Although the US contended that MOFCOM could have gathered information on all domestic producers through other sources identified by the US, 96 the Panel determined that China's actions in dealing with those options did not amount to 'a material risk of distortion in the injury determination' ${ }^{97}$ Therefore, the Panel found that the US had not demonstrated a violation on the part of MOFCOM by defining the domestic industry through biased selection under Articles 3.1 and 4.1 of the ADA and Articles 15.1 and 16.1 of the SCM Agreement.

In light of the above, the Panel held that MOFCOM was not required under Articles 4.1 and 16.1 to identify and seek information from all domestic producers and the US had not established that China acted inconsistently with the obligations set forth by Articles 3.1 and 4.1 of the ADA and Articles 15.1 and 16.1 of the SCM Agreement in defining the domestic industry.

Price effects' analyses under Articles 3.1, 3.2 and 12.2.2 of the ADA and Articles 15.1, 15.2 and 22.5 of the SCM Agreement. The US' claims with respect to MOFCOM's price effects analyses involved mainly three aspects.

94 Ibid., at paras. 7.422-7.423.

95 Ibid., at para. 7.430 .

96 The US noted three other sources: (1) the consultant's report in Exhibit 6 to the petition, (2) the Chinese Ministry of Agriculture, and (3) the domestic producers mentioned by USAPEEC.

97 The Panel found the consultant's report in Exhibit 6 to be lacking in terms of identification and contact information for the producers. China argued that its Ministry of Agriculture had no data on all producers in China and the Panel accepted this explanation. With regard to the four producers identified by USAPEEC, China demonstrated that three of them responded on either an individual or a consolidated basis. The last one was not contacted by MOFCOM, but USAPEEC's information on this producer was received after MOFCOM had obtained information from producers accounting for more than $50 \%$ of the total domestic production. The Panel reasoned that MOFCOM's less-than-ideal actions were not enough to give rise to a material risk of distortion. Panel Report, China-Broiler Products, paras. 7.4317.434 . 
Regarding the price undercutting analyses, the US argued that MOFCOM's analyses were based on flawed price comparisons of average unit prices at different levels of trade and comprised different product mixes. For the price suppression analyses, the US submitted that these are based on the flawed price undercutting analyses and MOFCOM failed to determine that the price suppression was the effect of the subject imports. In addition, the US alleged that MOFCOM's failure to disclose the methodology of adjustment of the import price data with respect to the different levels of trade and to provide in the final determinations the reason/s for its rejection of the interested parties' argument concerning the level of trade was in violation of Articles 12.2.2 of the ADA and 22.5 of the SCM Agreement.

As regards price effects, Article 3.2 of the ADA provides in relevant part: ${ }^{98}$

With regard to the effect of the dumped imports on prices, the investigating authorities shall consider whether there has been a significant price undercutting by the dumped imports as compared with the price of a like product of the importing Member, or whether the effect of such imports is otherwise to depress prices to a significant degree or prevent price increases, which otherwise would have occurred, to a significant degree. No one or several of these factors can necessarily give decisive guidance.

\section{Price undercutting analyses}

The Panel noted that the principal issue with regard to the price undercutting analyses was whether MOFCOM ensured comparability of the two sets of prices that it compared in the context of Articles 3.2 of the ADA and 15.2 of the SCM Agreement. According to the Panel, although no specific methodologies are imposed by Articles 3.1 and 3.2 of the ADA or Articles 15.1 and 15.2 of the SCM Agreement for the price effects analyses and investigating authorities have discretion in this regard, this discretion is limited by the 'overarching obligation under Articles 3.1 and 15.1 that the determination of injury "be based on positive evidence and involve an objective examination". 99 The Panel noted that 'there can be no question that the prices being compared must correspond to products and transactions that are comparable if they are to provide any reliable indication of the existence and extent of price undercutting by the dumped or subsidized imports as compared with the price of the domestic like product, which may then be relied upon in assessing causality between subject imports and the injury to the domestic industry'. ${ }^{100}$ The Panel further stated that in the recent ChinaGOES dispute, the Appellate Body expressly explained that:

98 Article 15.2 of the SCM Agreement is identical to Article 3.2 of the ADA except the words 'dumped imports' are replaced with 'subsidized imports'. We also note that the texts of Articles 3.1 of the ADA and 15.1 of the SCM Agreement have been provided in Section 3.2.3 above.

99 Panel Report, China-Broiler Products, para. 7.476.

100 Panel Report, China-Broiler Products, para. 7.475. 
[a]lthough there is no explicit requirement in Articles 3.2 and 15.2, we do not see how a failure to ensure price comparability could be consistent with the requirement under Articles 3.1 and 15.1 that a determination on injury be based on 'positive evidence' and involve an 'objective examination' of, inter alia, the effect of subject imports on the prices of domestic like products. ${ }^{101}$

The Panel determined that the concept of level of trade is relevant to the price comparison even though it is not specifically referred to in the various paragraphs of Article 3, and held that the US did not convince it that MOFCOM needed to add a mark-up corresponding to the importer's costs and profit to the subject import average unit price (AUV) to render it comparable to the domestic price AUV. ${ }^{102}$ This is because the Panel considered the CIF price to which appropriate adjustments are made to reflect the price paid by the importer as 'the first purchaser in the country of import' comparable to and at the same level of trade as the ex-works price paid by the first purchaser in the importing country as they are the prices upon which the 'first' purchaser in the country of import will base its purchasing decision to either import directly or to buy directly from domestic producers. ${ }^{103}$

However, as regards the product mix, the Panel determined that the differences in product mix identified by it risked affecting price comparability and distorting any price effects analysis if steps were not taken to control for product mix, or necessary adjustments made. It found that MOFCOM failed to take the necessary steps to ensure the price comparability to account for the variations in the product mix, as the imports from the US were limited to certain chicken parts which included a high proportion of paws, ${ }^{104}$ wings and legs, whereas the Chinese domestic producers' sales included all other parts of the chicken, such as breast meat. ${ }^{105}$ The Panel was of the view that MOFCOM should not have neglected such wellknown market realities in comparing the prices.

In conclusion, the Panel held that the US had not established that China acted inconsistently with Articles 3.1 and 3.2 of the ADA and Articles 15.1 and 15.2 of the SCM Agreement because MOFCOM relied for its findings of price undercutting on a comparison of subject import and domestic AUVs at different levels of trade; but it considered that China had acted inconsistently with Articles 3.1 and 3.2 of the ADA and Articles 15.1 and 15.2 of the SCM Agreement with respect to MOFCOM's reliance for its price undercutting analyses on a comparison of subject import and domestic AUVs that included different product mixes without

101 Panel Report, China-Broiler Products, para. 7.477, citing to the Appellate Body Report, ChinaGOES, para. 200, footnote omitted.

102 Panel Report, China-Broiler Products, para. 7.486.

103 Ibid.

104 Paws were the largest volume broiler part exported to China.

105 Ibid., at para. 7.490 . 
taking any steps to control for differences in the physical characteristics affecting price comparability or making necessary adjustments. ${ }^{106}$

\section{Price suppression analyses}

The US also alleged that MOFCOM's price suppression findings were inconsistent with Articles 3.1 and 3.2 of the ADA and Articles 15.1 and 15.2 of the SCM Agreement. Although China argued that its price suppression determination was independent from its price undercutting analysis, the Panel established that the two issues were 'closely interlinked' for MOFCOM and that the former was at least partially dependent on the latter. ${ }^{107}$ Given the Panel's finding of price undercutting being inconsistent with Articles 3.1, 3.2, 15.1, and 15.2, it had to consider whether China's price suppression determination could stand on its own, meaning whether the finding of price suppression could be reached independently on the basis of MOFCOM's findings on the volume and increased market share effects.

The Panel compared the situation of the present case to the one evaluated by the Appellate Body in China-GOES, where the Appellate Body upheld that it was 'not possible to conclude that MOFCOM's finding that price depression was an effect of subject imports might be upheld purely on the basis of MOFCOM's findings regarding the effect of the increase in the volume of subject imports' ${ }^{\prime 08}$ and held that it reached a similar conclusion. The Panel considered that MOFCOM's determinations did not discuss the impact of the volume and increased market share of subject imports on the ability of domestic producers to sell at prices that would cover their costs of production and it could not separate the respective contribution, in MOFCOM's determinations, of price undercutting and of volume and market share effects on the resulting price suppression. As a consequence, it could not uphold MOFCOM's price suppression findings in light of its earlier finding on the price undercutting determination. ${ }^{109}$ Accordingly, it held that China acted inconsistently with Articles 3.1 and 3.2 of the ADA and Articles 15.1 and 15.2 of the SCM Agreement because it failed to determine that price suppression was an 'effect' of the subject imports.

3. Failure to provide reasons for rejecting the US Government's argument under Article 12.2 of the ADA and Article 22.5 of the SCM Agreement

Last, the Panel evaluated whether MOFCOM provided reasons for rejecting the US Government's argument concerning the adjustment for the level of trade in MOFCOM's price effects analysis. The US submitted that MOFCOM seemed to acknowledge in the determinations that the import and domestic price data were

106 Panel Report, China-Broiler Products, para. 7.494.

107 Ibid., at paras. 7.508-7.509.

108 Panel Report, China-Broiler Products, para. 7.510, citing to the Appellate Body Report, ChinaGOES, paras. 220-221.

109 Panel Report, China-Broiler Products, para. 7.511. 
at different levels of trade, but then it neglected to give any reasons as to why it made no adjustment to that end nor provided any explanations for rejecting the US Government's argument. China claimed that the issue fell outside of the Panel's term of reference because the US' Panel request identified Articles 12.2 of the ADA and 22.3 of the SCM Agreement with respect to this issue, but then it had made arguments under Articles 12.2.2 of the ADA and 22.5 of the SCM Agreement in the submissions to the Panel. The Panel found that the obligations under Article 12.2 of the ADA, including Articles 12.2.1 and 12.2.2, and Article 22 of the SCM Agreement, including Articles 22.3 and 22.5, were inter-related, and when considered as a whole, the Panel request 'succeed[ed] in signaling the United States' intention to pursue claims concerning MOFCOM's failure to explain the reasons for its reject of US respondents' arguments concerning price effects, including the question of the difference in levels of trade, under not only the provisions listed under paragraph 16, but also under those cited under paragraph 25 of the Panel request'. ${ }^{110}$

After finding the US' claim to be within its terms of reference, the Panel considered whether the claim was one of 'issues of fact and law considered material' by MOFCOM from the perspective of the determinations at issue per Articles 12.2.2 and 22.5, ${ }^{111}$ and, if so, whether MOFCOM's determinations provided the reasons for rejecting the argument regarding the level of trade in sufficient detail for the US Government to understand why its argument was treated in such a manner. In view of the earlier discussions on the level of trade in relation to the price analyses, the Panel found the argument concerning the level of trade to be a material one, and that MOFCOM only acknowledged the US' argument but failed to disclose its reasons for the rejection of the argument in the public notice of its final determinations or a separate report. Therefore, the Panel held that China had acted inconsistently with Articles 12.2.2 and 22.5.

Adverse impact of subject imports on the domestic industry under Articles 3.1 and 3.4 of the ADA and Articles 15.1 and 15.4 of the SCM. According to the US, MOFCOM's findings that the subject imports had an adverse impact on the domestic industry were not based on an 'objective examination' of 'all relevant economic factors and indices having a bearing on the state of the industry', in breach of Articles 3.1 and 3.4 of the ADA and Articles 15.1 and 15.4 of the SCM Agreement. ${ }^{112}$ In particular, the US argued that MOFCOM's adverse

110 Ibid., at para. 7.522 .

111 The text of Article 12.2.2 has been provided in the Section 3.2.1 above.

112 Article 3.4 of the ADA provides:'The examination of the impact of the dumped imports on the domestic industry concerned shall include an evaluation of all relevant economic factors and indices having a bearing on the state of the industry, including actual and potential decline in sales, profits, output, market share, productivity, return on investments, or utilization of capacity; factors affecting domestic prices; the magnitude of the margin of dumping; actual and potential negative effects on cash flow, 
impact finding is based on the flawed analysis of only two factors, i.e., capacity utilization and end-of-period inventories and it disregarded all the other factors that showed a robust and improving performance of the domestic industry.

The Panel noted that Articles 3.1 of the ADA and 15.1 of the SCM Agreement require that the investigating authority's assessment of the evidence must be objective and this may require the investigating authority to 'place the relevant data in context of a manner that is informative of the injury, if any, suffered by the domestic industry rather than simply review evolution in yearly figures'. ${ }^{113}$. However, the Panel stated that it did not consider it necessary to reach findings with respect to the US' claim in view of its earlier findings on MOFCOM's price undercutting and price suppression determinations, because the implementation of those Panel findings would require MOFCOM to re-evaluate its adverse impact assessment in any event. ${ }^{114}$ Consequently, the Panel considered that it did not need to make additional findings with respect to the adverse impact of the subject imports on the domestic industry.

Causation analyses under Articles 3.1, 3.5, 12.2, and 12.2.2 of the ADA and Articles 15.1, 15.5, 22.3, and 22.5 of the SCM Agreement. The US made a twopart claim regarding the causation analyses. First, it argued that China had acted inconsistently with Articles 3.1 and 3.5 of the ADA and Articles 15.1 and 15.5 of the SCM Agreement because MOFCOM ignored evidence that the volume and market share of the subject imports did not increase at the expense of the domestic industry, the causation analysis relied upon the flawed price undercutting analysis, and MOFCOM failed to reconcile the causation analyses with the evidence that the domestic industry's performance improved even as the import volume and market share increased during 2006-2008. Second, the US alleged that China acted inconsistently with the procedural obligations of Articles 12.2 and 12.2.2 of the ADA and Articles 22.3 and 22.5 of the SCM Agreement by not explaining its reasons for rejecting the US interested parties' two arguments regarding causation. ${ }^{115}$

With respect to the first part of the claim, the Panel declined to make any findings. It noted that it had already concluded that MOFCOM's findings of price undercutting and price suppression were inconsistent with Articles 3.1 and

inventories, employment, wages, growth, ability to raise capital or investments. This list is not exhaustive, nor can one or several of these factors necessarily give decisive guidance'. Article 15.4 of the SCM Agreement is largely similar to Article 3.4 of the ADA, except that it uses 'subsidized imports' instead of 'dumped imports' and contains the following additional sentence after listing the factors in the first sentence: 'ability to raise capital or investments and, in the case of agriculture, whether there has been an increased burden on government support programmes'. It is noted that the texts of Articles 3.1 and 15.1 are provided in the earlier Section 3.2.3 of this paper.

113 Panel Report, China-Broiler Products, para. 7.554.

114 Ibid., at para. 7.555 .

115 Ibid., at paras. $7.558-7.559$. 
3.2 of the ADA and 15.1 and 15.2 of the SCM Agreement and in light of the relationship between the pricing analysis under Articles 3.2 and 15.2 and the causation analysis under Articles 3.5 and 15.5, it could not conclude that MOFCOM's causation analysis was proper.

The second part of the claim was similar to the one made by the US with respect to the price effects analyses under the same articles as discussed in the earlier section, and the Panel recalled its earlier analysis in setting out the specific issues that it had to address namely: (i) whether the two arguments raised by the US interested party addressed 'issues of fact and law considered material' by MOFCOM from the perspective of the determinations at issue; and, if so, (ii) whether MOFCOM's public notices of the final determinations provided the reasons in sufficient detail for its rejection of each argument to allow the US interested party to understand why its arguments were treated as they were, and to assess whether or not MOFCOM's treatment of the relevant issue was consistent with domestic law and/or the covered agreements. 116

The USA Poultry and Egg Export Council (USAPEEC) argued in its injury comments that the subject imports only accounted for a very small percentage of the Chinese domestic market during the POI, that there was no considerable increase in imports, the imports only filled-up the gap which was left open by other foreign producers, and thus the increase in market share of the subject imports was not to the determinant of the domestic industry. The Panel considered the argument relevant to material issues of fact and law as it related to market share gains by the subject imports, which was a significant factor in MOFCOM's causation finding. ${ }^{117}$ The Panel also found that MOFCOM rejected this argument in the final determination on the ground that the domestic industry was injured even though domestic producers increased their market share because subject imports had increased in absolute terms, and due to the price undercutting and price suppression by the subject imports. In the Panel's view, MOFCOM's reasoning for rejecting USAPEEC's argument was sufficient under the requirements of the concerned articles.

USAPEEC also contended that the subject imports could not have had an adverse impact on the domestic industry because over $40 \%$ of them consisted of chicken paws, which Chinese producers were incapable of supplying adequately for its domestic market. This was determined by the Panel as a relevant issue since it factored into the causation analysis of MOFCOM. ${ }^{118}$ The Panel noted that while MOFCOM addressed the argument in its preliminary determinations, stating that it considered all chicken parts to be in competition and interchangeable with one another, it failed to acknowledge or address it at all in its final determinations. 
Thus, the Panel found that MOFCOM violated the obligations under the concerned articles and even a simple reference to the treatment of the issue in the preliminary determinations would have been sufficient. ${ }^{119}$

In conclusion, the Panel held that the US did not establish that China acted inconsistently with Articles 12.2 and 12.2.2 of the ADA and Articles 22.3 and 22.5 of the SCM Agreement with respect to USAPEEC's argument regarding market share, but it did rule that MOFCOM failed to provide reasons for rejecting USAPEEC's argument concerning the incapability of Chinese producers to adequately supply chicken paws.

Last, on the basis of the foregoing findings, the Panel also held that China acted inconsistently with Article 1 of the ADA and Article 10 of the SCM Agreement to the extent the Panel upheld the US' claims. ${ }^{120}$

\section{Legal and economic analysis}

\subsection{Introduction}

Many of the US' claims in the present case were similar to those raised by the US in an earlier WTO dispute brought by the US against China on the latter's imposition of AD and CVD duties on US exports of grain oriented flat-rolled electrical steel. ${ }^{121}$ As we have already analyzed these in one of our previous articles, ${ }^{122}$ we will not analyze them in this article again. This observation relates to the adequacy of non-confidential summaries and of the disclosure, the calculation of the 'all others' rate in both the AD and the CVD proceedings, and the use of facts available in that regard, as well as the price effects' analysis in the injury context.

Rather, we will address what we believe is the most interesting issue in this dispute, namely the problem of allocating the cost of a chicken over the various chicken parts.

\subsection{Issues related to cost of production calculation and allocation}

\subsubsection{Case-specific details}

A 'normal' dumping margin calculation typically compares a normal value based on the domestic prices of the exporting producers with those charged by them for export to the importing country whose authorities are conducting the investigation. Such price-based comparisons tend to be based on 'hard' data and are

119 Ibid., at para. 7.605 .

120 Ibid., at paras. $7.608-7.613$.

121 Appellate Body Report, China-Countervailing and Anti-Dumping Duties on Grain Oriented Flat-Rolled Electrical Steel from the United States, WT/DS414/AB/R, adopted 16 November 2012.

122 See Thomas J. Prusa and Edwin Vermulst, 'China - Countervailing and Anti-dumping Duties on Grain Oriented Flat-rolled Electrical Steel from the United States: Exporting US AD/CVD methodologies through WTO dispute settlement?', 13:2 World Trade Review, 229-266 (2014). 
relatively easy to make and to check - as long as the sales channels are simple 123 and the product control numbers $(\mathrm{PCNs})^{124}$ are non-controversial. However, if there are no or no representative ${ }^{125}$ domestic sales of the product concerned or domestic sales are not made in the ordinary course of trade, or the authorities determine that a particular market situation exists, the authorities may decide to base normal value on constructed normal values, normally on a PCN-by-PCN basis. Such constructed normal values per Article 2.2 ADA consist of three elements:

- the cost of production ${ }^{126}$ in the country of origin [emphasis added]; plus

- a reasonable amount for administrative, selling and general (SGA) costs; plus

- a reasonable amount for profits.

It may be clear that the establishment of a normal value based on constructed normal values on a PCN-by-PCN basis therefore involves both cost calculations and cost allocations, the latter both between the subject product and the nonsubject products, and among the various PCNs. Article 2.2.1.1 ADA contains two important provisions in this regard. ${ }^{127}$

The first sentence of Article 2.2.1.1 provides that for the purpose of Article 2.2, costs shall normally be calculated on the basis of records kept by the exporter or producer under investigation, provided that (1) such records are in accordance with the generally accepted accounting principles (GAAP) of the exporting country and (2) reasonably reflect the costs associated with the production and sale of the product under consideration (emphasis added). The second sentence of Article 2.2.1.1 then requires administering authorities to 'consider all available evidence on the proper allocation of costs, including that which is made available by the exporter or producer in the course of the investigation, provided that such allocations have been historically utilized by the exporter or producer' [emphasis added].

123 If sales channels are more complicated, for example, because the product concerned is imported through a related importer, the process of construction of the export price will involve cost calculations and allocations as well as attribution of a reasonable profit to the related importer's activities which may give rise to arbitrary decisions.

124 PCNs are sub-divisions of the product concerned established by the importing country administering authorities in the context of a trade remedies' proceeding for the purpose of making more precise calculations. In many countries, however, foreign exporters and importers are not consulted on the establishment of the PCNs (although the complainant producers normally are), which may give rise to result-oriented PCN classifications.

125 Domestic sales should normally represent at least $5 \%$ of export sales. This $5 \%$ test tends to be applied both on a producer-specific basis and on a PCN-by-PCN basis. Notably because of the latter, it often happens that certain exported PCNs are found not to have been sold in sufficient quantities in the domestic market, for example, because of differences in consumer tastes, as seems to have been the case here.

126 A better term would probably be 'cost of manufacture' as it typically relates to costs incurred in the factory where the product is made.

127 It is not completely clear whether the cost calculation and allocation rules of Article 2.2.1.1 apply only to the first bullet point ('cost of production') or also to the establishment of SGA in light of the fact that Article 2.2.2 contains special provisions with regard to the establishment of the SGA. Yet SGA normally will also need to be allocated. 
In the case at hand, the scope of the investigations was defined as broiler products or chicken products originating in the US and according to the specific description of the subject merchandise, this included chicken products in which a whole broiler is slaughtered and processed, including whole chicken without cutting into pieces, cuts and offal, side products of chicken products, fresh, chilled or frozen. ${ }^{128}$ The scope therefore covered both whole chickens and chicken parts, such as breasts, thighs, leg quarters, chicken wings, wing tips, paws (feet), and residual products (offal).

As we have seen above in Section 3.2.1, the Panel managed to deal with the main Article 2.2.1.1 claims on procedural grounds. Thus, the Panel considered that if an investigating authority for cost calculation purposes wishes to deviate from the records of the producers under investigation, it must explain on the record of the investigation why it decides to do so, which China had not done with regard to Tyson and Keystone. ${ }^{129}$

As regards China's use of a weight-based allocation method rather than the value-based allocation methods used by the three respondents, the Panel ruled that China violated Article 2.2.1.1, second sentence, because China could not provide evidence on the record that it had 'deliberated or explained the weightbased methodology it chose to apply or why it chose that methodology over the alternatives provided by the respondents' ${ }^{130}$

The Panel also ruled against China on two specific cost allocation issues on the ground that they were not 'proper' within the meaning of Article 2.2.1.1, second sentence. First, MOFCOM's straight weight-based allocation method incorrectly allocated all costs over all products, even though certain processing costs would be incurred only for certain chicken parts, such as, for example, skinning, deboning, and deveining costs to produce breast meat. ${ }^{131}$ Second, in the case of Tyson, MOFCOM had allocated production costs related to non-subject products to subject products. ${ }^{132}$ It seems to us that these two issues really pertain to what one might call 'calculation logic'.

Thus, all of the Panel's rebukes regarding the cost issue were procedural and supposedly can be easily corrected by China. By focusing on procedural and calculation logic issues, the Panel managed to avoid having to decide on the more difficult - but conceptually more interesting - substantive costing issues arising in cases such as this ${ }^{133}$ where several products emanate up to a point from the

128 Live chicken, chicken products in a can or other kind of package or preservative, the chicken sausage and like products, and cooked chicken products were excluded from the scope. See Panel Report, China-Broiler Products, footnote 8.

129 The Panel found that MOFCOM had adequately explained on the record why it decided not to use the cost calculations of Pilgrim's Pride.

130 Panel Report, China-Broiler Products, para. 7.194.

131 Panel Report, China-Broiler Products, para. 7.196 and footnote 338.

132 Panel Report, China-Broiler Products, para. 7.197.

133 Other industries where similar issues might arise according to Tyson include poultry more in general, beef, ham, citrus fruits, and petrochemicals, see Panel Report, China-Broiler Products, footnote 197. 
same production process(es). This may yield either joint or co-products or main products and by-products, and, as we will see, the dividing line between the two is not always clear.

The US, China, and the three investigated US respondents were in agreement that 'in the case of joint products, which arise at a split-off point, pre-split-off costs cannot be directly assigned on a product-specific basis' as a result of which they must be allocated. ${ }^{134}$ The Panel in a footnote provides a useful example of a value-based allocation method, which also addresses the importance of classifying products as joint products or by-products:

Our understanding of the methodology is that companies producing joint or coproducts which have a single production cost up to a certain point allocate that cost across the various resulting products according to the proportion of revenue those products will earn in the market. For example, if a single chicken was divided up and the breast sold for $\$ 5$, the thigh for $\$ 2$, the wings for $\$ 2$, and the paws for $\$ 1$, then $50 \%$ of the pre-split-off costs would be allocated to the breast, $20 \%$ to thighs and wings respectively and $10 \%$ to paws. However, if there were other products that were by-products, in that they were inevitably produced as part of making a chicken, but were not part of the commercial business of the firm - such as blood, feathers, gizzards, etc... then these would have none of the pre-split-off costs assigned to them and would only have specific post-split-off costs recorded (such as processing, disposal, or packaging)'.

That is, the cost of the whole chicken can be written as

$$
T C=C_{\text {pre-split }}+C_{\text {post-split }}
$$

and the pre-split cost can be written

$$
C_{\text {pre-split }}=C_{\text {breast }}+C_{\text {thigh }}+C_{\text {wing }}+C_{\text {leg }}+C_{\text {paw }}+C_{\text {offal }} \text {. }
$$

The legal and economic matter of interest in the case stems from the fact that while certain costs $\left(C_{\text {pre-split }}, C_{\text {post-split }}\right)$ are observed, the pre-split cost of each separate part is not observed as it must be imputed (or allocated). For instance, the presplit costs can be written

$$
C_{\text {pre-split }}=\left(\alpha_{\text {breast }}+\alpha_{\text {thigh }}+\alpha_{\text {wing }}+\alpha_{\text {leg }}+\alpha_{\text {paw }}+\alpha_{\text {offal }}\right) C_{\text {pre-split }},
$$

where the shares $\left(a_{i}\right)$ sum to 1 .

However, and not surprisingly in light of the consequences of the methodology followed, the parties disagreed on the allocation methodologies in such cases and on whether the three respondents had in fact treated/costed major exported products such as paws as joint products or as by-products. ${ }^{135}$ As regards the allocation 
of the common pre-split meat costs, the US producers' approach was to allocate the pre-split-off costs relative to the sales value of the paws while the post-split costs were product-specific. This likely negated the dumping claim, whereas China's method involved a weight-based allocation of the total pre-and post-split costs, i.e., the total product-specific production costs of the various product types were divided by the total product specific production volumes reported. The resulting per pound cost was applied to a pound of the breast meat, wings, paws, and the other products ${ }^{136}$ implying a relatively high pre-split cost for the paws leading to a finding of sales below cost. The Panel was of the view that 'neither method is in principle inherently unreasonable', but did not further expand on this as it decided the issue on procedural grounds. ${ }^{137}$

\subsubsection{Value-based methodology}

The investigated US producers Tyson, Keystone, and Pilgrim's Pride claimed to have used 'relative sales value' methodologies [hereinafter: value-based methodology] to allocate the pre-split-off costs to the paws. ${ }^{138}$ The shares under a value-based method can be written as

$$
\alpha_{i}=\frac{P_{i}}{P_{\text {whole }}},
$$

where $P_{i}$ denotes part $i$ 's sales price and $P_{\text {whole }}$ denotes the price of the whole chicken (on a per kilogram basis). ${ }^{139}$

Tyson, for example, explained that:

'Meat costs are allocated based on a value-based cost allocation. For wing tips, paws and gizzards, the meat cost is assigned based on the offal market price. The offal market price is then adjusted using a formula to account for freight and processing costs to arrive at a meat value for these products. This is called the 'offal credit'. For leg quarters, the meat cost is determined based on the market price for leg quarters. This is called the dark meat credit. The remaining meat costs (total meat cost minus the offal credit and the dark meat credit) are assigned to the front half of the bird, i.e., the white/breast meat'. ${ }^{140}$

136 US first written submission in China-Broiler Products, paras. 110-112 The US noted, 'the importance of the decision to apply the methodology MOFCOM arrived at cannot be overstated. Its application was potentially dispositive in determining the existence of dumping'. (http://www.ustr.gov/webfm_send/ 3490).

137 Panel Report, China-Broiler Products, para. 7.167.

138 Panel Report, China-Broiler Products, para. 7.114.

139 We note that US producers utilized a somewhat more sophisticated value method wherein they made adjustments to the observed market prices before computing the cost shares; in addition, in the case of Tyson the price of offal was used instead of an actual price for paws. Consequently, for US producers cost shares were not exactly the same as shares based on observed prices. We abstract from this extra level of complication as it serves to obfuscate the main idea.

140 Panel Report, China-Broiler Products, para. 7.115. 
Similarly, Pilgrim's Pride explained that:

the meat costs of the chicken are assigned to the prime value product, chicken breasts, with other pieces of the chicken receiving costs based upon their relative values in the market place. These by-products are assigned a meat value plus processing cost equal to the estimated future market value at the time of standard cost updates performed each quarter. ${ }^{141}$

All US producers treated paws as products with little to no value. The Panel noted that Keystone and Pilgrim's Pride 'affirmatively expressed that they treat paws as by-products' ${ }^{142}$ According to China, Tyson did not use its domestic sales prices of paws, but rather reference prices from a commodity pricing service, Urner Barry, which used one price for a basket of goods that included paws and other products such as wing tips, gizzards, and contaminated meat, which effectively reflected a by-product approach, rather than joint-product accounting. ${ }^{143}$ Regardless of this issue, however, the three producers allocated the pre-split-off costs on the basis of the relative sales values of the paws.

The US producers' method was GAAP consistent and they provided significant support for the reasonableness of their methodology, yet it could be questioned from an economics perspective on several grounds. ${ }^{144}$

First, whether at some point in the past the economic value of paws was simple waste material seems largely irrelevant for the current allocation problem. The fact that US producers have exported, and continue to export, hundreds of millions of dollars of chicken paws each year belies the argument that paws have an economic value equivalent to waste material. Chicken paws are widely recognized by the US industry as a valuable source of profits. In fact, according to Carlos Ayala, Vice President at Perdue Farms, since the mid-1990s chicken paws have been 'one of the most profitable items that we have. In fact, there are a lot of chicken companies that would be out of business if it were not for the chicken paws'. ${ }^{145}$ However, the US producers' treatment of paws means the computed paw cost is very low.

Furthermore, there is a glitch: the US' argument is circular-costs are used to determine the fairness of a sales value, but the sales value is used to determine the cost. In fact, a succinct description of the problem comes from the US Department of Commerce (USDOC):

141 Panel Report, China-Broiler Products, para. 7.117. The cost calculations and allocations of Keystone were treated as BCI by the Panel.

142 Panel Report, China-Broiler Products, footnote 294.

143 Panel Report, China-Broiler Products, para. 7.168 and footnote 294.

144 MOFCOM rejected Pilgrim's cost not simply because of the allocation methodology but also because Pilgrim's cost records were irreconcilable. The United States did not challenged MOFCOM's decision to reject Pilgrim's Pride cost data based on the irregularities found in that data.

145 Stephen J. Dubner, 'Weird Recycling', National Public Radio Freakonomics Radio Podcast, 5 December 2011, at http://freakonomics.com/2011/12/05/weird-recycling-a-new-freakonomics-radiopodcast/. 
We recognize that a value-based cost allocation can be problematic in an antidumping context. The most obvious problem is the potential circularity of the analysis, whereby prices are used to determine the product-specific costs which in turn are either compared to those same product-specific prices or are used to determine prices (i.e., through the sales-below-cost test and constructed value). ${ }^{146}$

In fact, the USDOC has previously argued that a value-based cost allocation in an anti-dumping context gives rise not to just potential circularity, but what the US authorities call 'inherent' circularity. ${ }^{147}$ Perhaps the strongest statement regarding the problematic nature of value-based cost accounting is found in a US Federal Circuit Court ruling (in a case where the court ruled in favor of the USDOC's rejection of value-based cost accounting) which stated:

This circular reasoning contravened the express requirements of the statute which set forth the cost of production as an independent standard for fair value'. ${ }^{148}$

Second, the sales price values $\left(P_{i}\right)$ by and large seem to have been based on sales values in the US (except for Tyson). ${ }^{149}$ The use of a domestic price for cost allocation is problematic from an economic perspective given that most chicken paws are exported. Basic economic theory says that one should value the chicken paws at their 'next best alternative'. Implicit in the US' position is that 'but for' China the chicken paws would be sold at very low prices. This is not supported by the facts. While China was a large export market, the US exported chicken paws to over 100 countries in 2008.150 There is no reason to assume that 'but for' China, US producers would be selling paws at very low value. ${ }^{151}$

Third, since there appears to be a very small US market price for paws what price could the US (or MOFCOM) have used? One alternative to valuing the paws at a low price would be to use the export price to an appropriate third country as the basis for normal value, a possibility in fact explicitly foreseen in Article 2.2 ADA. In Table 2, we report the average US export price for chicken paws to the five largest export markets (other than China). As seen, in every export market chicken paws were valued at prices similar to those for Chinese exports and all prices were substantially different from zero. In fact, in 2008, the last full year before the case was initiated by China, the US export price to China was lower

146 Notice of Final Results of Anti-dumping Duty Administrative Review and Notice of Final Results of Anti-dumping Duty Changed Circumstances Review: Certain Softwood Lumber Products from Canada, 69 Fed. Reg. 75921 (20 December 2004).

147 See Results of Redetermination Pursuant to Remand, PSC VSMPO-Avisma Corp. v. United States, Consol. Court No. 08-00321 (CIT 20 October 2009).

148 IPSCO, Inc. v. United States, 965 F.2d 1056, 1061 (Fed. Cir. 1992).

149 Panel Report, China-Broiler Products, para. 7.137.

150 Based on US export data, HS code 020714, 'Cuts \& edible offal of chicken' (US International Trade Commission Dataweb). This is the 6-digit HS code containing chicken paws.

151 As we will discuss below, evidence shows that US producers responded to the Chinese duties by dramatically increasing their exports of chicken parts (including paws) to other markets. 
Table 2. Average US export price (chicken paws)

\begin{tabular}{lllll}
\hline \hline & 2005 & 2006 & 2007 & 2008 \\
\hline China & $\$ 0.79$ & $\$ 0.75$ & $\$ 0.82$ & $\$ 0.90$ \\
Russia & $\$ 0.85$ & $\$ 0.60$ & $\$ 0.87$ & $\$ 0.97$ \\
Ukraine & $\$ 1.11$ & $\$ 0.62$ & $\$ 0.90$ & $\$ 1.07$ \\
Cuba & $\$ 0.76$ & $\$ 0.56$ & $\$ 0.80$ & $\$ 0.94$ \\
Mexico & $\$ 0.85$ & $\$ 0.80$ & $\$ 1.03$ & $\$ 0.96$ \\
Hong Kong & $\$ 0.78$ & $\$ 0.89$ & $\$ 0.89$ & $\$ 0.92$ \\
$\begin{array}{l}\text { Average-All export markets } \\
\text { except for China }\end{array}$ & $\$ 0.85$ & $\$ 0.68$ & $\$ 0.92$ & $\$ 1.01$ \\
\hline \hline
\end{tabular}

Note: Based on US export data, HS code 020714.

than any of the other five largest destination markets. This suggests that had MOFCOM used a third country price for its cost allocation, it would have found dumping.

From an economics perspective, one could also envisage using an average of US domestic and export (excluding China) prices as the basis for a value-based constructed normal value, but legally this does not appear permissible, as the rule in Article 2.2 to use cost of production in the country of origin is absolute. As noted, the Panel did not confirm the US producers' method, but rather simply stated that MOFCOM's method failed to adequately explain the deficiencies in the US producers' approach.

\subsubsection{Weight-based methodology}

In its preliminary determination, MOFCOM decided not to use the respondents' value-based cost allocation methodologies on the ground that they did not reasonably reflect the production costs of the subject products in the case of Tyson and Keystone and that there were mistakes in the calculations in the case of Pilgrim's Pride. While MOFCOM could have chosen to accept the value-based methods and develop alternative weights, it instead decided to use its own methodology by which it allocated the total pre-and post-split-off costs reported by the US producers based on the total weight of the various chicken products pertaining to those costs [hereinafter: weight-based methodology]. MOFCOM's approach can be written as

$$
\alpha_{i}=\frac{W T_{i}}{W T_{\text {whole }}},
$$

where $W T_{i}$ denotes part $i$ 's weight and $W T_{\text {whole }}$ denotes the weight of the whole chicken.

Numerical examples may help convey how the methods work. In Table 3, costs are allocated according to the value-based approach proposed by the US producers. 
Table 3. Example of cost accounting (value-based) Chicken paws valued according to the relative sales value

\begin{tabular}{lllllllll}
\hline \hline & $\begin{array}{l}\text { Export } \\
\text { price per } \\
\text { KG }\end{array}$ & $\begin{array}{l}\text { US market } \\
\text { price per } \\
\text { KG }\end{array}$ & Share & $\begin{array}{l}\text { Pre-split } \\
\text { meat costs }\end{array}$ & $\begin{array}{l}\text { Post-split } \\
\text { processing } \\
\text { costs }\end{array}$ & $\begin{array}{l}\text { Total } \\
\text { COP }\end{array}$ & $\begin{array}{l}\text { COP }+ \\
\text { SG\&A+ } \\
\text { profit }\end{array}$ & $\begin{array}{l}\text { Dumping } \\
\text { margin }\end{array}$ \\
\hline Breast & $\$ 4.90$ & $\$ 4.75$ & $64 \%$ & $\$ 3.31$ & $\$ 1.02$ & $\$ 4.33$ & $\$ 4.67$ & No \\
Thigh & $\$ 2.00$ & $\$ 1.50$ & $20 \%$ & $\$ 1.04$ & $\$ 0.30$ & $\$ 1.34$ & $\$ 1.45$ & No \\
Wings & $\$ 1.50$ & $\$ 1.00$ & $14 \%$ & $\$ 0.70$ & $\$ 0.20$ & $\$ 0.90$ & $\$ 0.97$ & No \\
Paw & $\$ 0.90$ & $\$ 0.10$ & $1 \%$ & $\$ 0.07$ & $\$ 0.02$ & $\$ 0.09$ & $\$ 0.10$ & No \\
Offal & - & $\$ 0.05$ & $1 \%$ & $\$ 0.03$ & $\$ 0.01$ & $\$ 0.04$ & $\$ 0.05$ & No \\
TOTAL & $\$ 9.30$ & $\$ 7.40$ & $100 \%$ & $\$ 5.15$ & $\$ 1.55$ & $\$ 6.70$ & $\$ 7.24$ & \\
\hline \hline
\end{tabular}

We also follow the US producers' approach where the pre-split costs are allocated based on the relative sales value. ${ }^{152}$ Normal value is calculated in three steps. First, we will compute all prices on a per kilogram basis. We assume total accounted presplit costs are $\$ 5.15$. The fundamental problem, of course, is how to allocate the total pre-split costs to the individual parts. Under a value-based method, the domestic sales price of thigh, wings, paws, and offal is observed and used to compute shares for purposes of allocating pre-split total costs. Second, we assume the post-split costs vary by part and can be observed on a part-by-part basis. Third, in order to construct the normal value for each part, the pre-and post-split costs per part are added to obtain the cost of production to which 5\% for SGA and $3 \%$ for profits are added. In such a case, the investigating authority compares the constructed normal value to the export price for each part and determines if dumping has occurred. In the example, there is no dumping for any of the parts.

To show how crucial the assumption that paws are cost-allocated using a low domestic valuation is, we reconsider the value-based approach but now we value the chicken paws using the price in a third market (e.g., $\$ 1 / \mathrm{KG}$ ). This example is given in Table 4. In this case, no adjustment for post-split costs, SG\&A, and profit has been made for the paws, as the export price would include post-split costs as well as SG\&A and profit. In contrast to the first example where no dumping existed, we now find that paws are dumped (margin of $11.11 \%$ ). ${ }^{153}$ The lesson from this example is that the US' preferred value-based method is not a panacea. MOFCOM could have adopted a value-based method and argued that adjustments to submitted prices were necessary to properly reflect relative valuations. 
Table 4. Example of cost accounting (value-based)

Chicken paws valued using the price to a third country markets $(\$ 1)$

\begin{tabular}{lllllllll}
\hline \hline & $\begin{array}{l}\text { Export } \\
\text { price per } \\
\text { KG }\end{array}$ & $\begin{array}{l}\text { US market } \\
\text { price per } \\
\text { KG }\end{array}$ & Share & $\begin{array}{l}\text { Pre-split } \\
\text { meat } \\
\text { costs }\end{array}$ & $\begin{array}{l}\text { Post-split } \\
\text { processing } \\
\text { costs }\end{array}$ & $\begin{array}{l}\text { Total } \\
\text { COP }\end{array}$ & $\begin{array}{l}\text { COP }+ \\
\text { SG\&A+ } \\
\text { profit }\end{array}$ & $\begin{array}{l}\text { Dumping } \\
\text { margin }\end{array}$ \\
\hline Breast & $\$ 4.90$ & $\$ 4.75$ & $64 \%$ & $\$ 3.31$ & $\$ 1.02$ & $\$ 4.33$ & $\$ 4.67$ & No \\
Thigh & $\$ 2.00$ & $\$ 1.50$ & $20 \%$ & $\$ 1.04$ & $\$ 0.30$ & $\$ 1.34$ & $\$ 1.45$ & No \\
Wings & $\$ 1.50$ & $\$ 1.00$ & $14 \%$ & $\$ 0.70$ & $\$ 0.20$ & $\$ 0.90$ & $\$ 0.97$ & No \\
Paw & $\$ 0.90$ & $\$ 1.00^{*}$ & $14 \%$ & - & - & - & $\$ 1.00$ & $11.11 \%$ \\
Offal & - & $\$ 0.05$ & $1 \%$ & $\$ 0.03$ & $\$ 0.01$ & $\$ 0.04$ & $\$ 0.05$ & No \\
\hline \hline
\end{tabular}

Note: *Paws valued using a third market price.

Table 5. Example of cost accounting (weight-based)

Both pre- and post-split costs allocated by weight

\begin{tabular}{lccccllll}
\hline \hline & $\begin{array}{l}\text { Export } \\
\text { price }\end{array}$ & Weight & Share & $\begin{array}{l}\text { Pre-split } \\
\text { meat costs }\end{array}$ & $\begin{array}{l}\text { Post-split } \\
\text { processing } \\
\text { costs }\end{array}$ & $\begin{array}{l}\text { Total } \\
\text { COP }\end{array}$ & $\begin{array}{l}\text { COP }+ \\
\text { SG\&A+ } \\
\text { profit }\end{array}$ & $\begin{array}{l}\text { Dumping } \\
\text { margin }\end{array}$ \\
\hline Breast & $\$ 4.90$ & 1.000 & $20 \%$ & $\$ 1.03$ & $\$ 0.31$ & $\$ 1.34$ & $\$ 1.45$ & No \\
Thigh & $\$ 2.00$ & 1.000 & $20 \%$ & $\$ 1.03$ & $\$ 0.31$ & $\$ 1.34$ & $\$ 1.45$ & No \\
Wings & $\$ 1.50$ & 1.000 & $20 \%$ & $\$ 1.03$ & $\$ 0.31$ & $\$ 1.34$ & $\$ 1.45$ & No \\
Paw & $\$ 0.90$ & 1.000 & $20 \%$ & $\$ 1.03$ & $\$ 0.31$ & $\$ 1.34$ & $\$ 1.45$ & $61.11 \%$ \\
Offal & - & 1.000 & $20 \%$ & $\$ 1.03$ & $\$ 0.31$ & $\$ 1.34$ & $\$ 1.45$ & No \\
\hline \hline
\end{tabular}

We now look at two examples of weight-based methodology. In the first example (Table 5), we follow MOFCOM's approach and allocate both pre- and post-split costs proportional to weight. In this example each part has weight $1 \mathrm{KG}$ yielding a $20 \%$ cost share. Given the total costs reported above (total pre-split costs of $\$ 5.15 / \mathrm{KG}$ and total post-split costs of $\$ 1.55 / \mathrm{KG})$, we find that MOFCOM's approach yields a total cost of production for each part of $\$ 1.34$. After a markup for SG\&A and profit, we have a per part cost of $\$ 1.45 / \mathrm{KG}$. Then comparing this constructed normal value with the export price for each part, we find that all parts are fairly priced except paws which are dumped at a margin of $61.11 \% .{ }^{154}$

In Table 6, we again allocate costs according to the weight-based approach, but here we only allocate the pre-split costs by weight. We assume in this example that the post-split costs are allocated according to the information provided by the subject producers. The process is similar to that in Table 5 for pre-split costs. 
Table 6. Example of cost accounting (weight-based)

Pre-split costs allocated by weight

\begin{tabular}{lccclllll}
\hline \hline & $\begin{array}{l}\text { Export } \\
\text { price }\end{array}$ & Weight & Share & $\begin{array}{l}\text { Pre-split } \\
\text { meat } \\
\text { costs }\end{array}$ & $\begin{array}{l}\text { Post-split } \\
\text { processing } \\
\text { costs }\end{array}$ & $\begin{array}{l}\text { Total } \\
\text { COP }\end{array}$ & $\begin{array}{l}\text { COP }+ \\
\text { SG\& }+ \\
\text { profit }\end{array}$ & $\begin{array}{l}\text { Dumping } \\
\text { margin }\end{array}$ \\
\hline Breast & $\$ 4.90$ & 1.000 & $20 \%$ & $\$ 1.03$ & $\$ 1.02$ & $\$ 2.05$ & $\$ 2.21$ & No \\
Thigh & $\$ 2.00$ & 1.000 & $20 \%$ & $\$ 1.03$ & $\$ 0.30$ & $\$ 1.33$ & $\$ 1.44$ & No \\
Wings & $\$ 1.50$ & 1.000 & $20 \%$ & $\$ 1.03$ & $\$ 0.20$ & $\$ 1.23$ & $\$ 1.33$ & No \\
Paw & $\$ 0.90$ & 1.000 & $20 \%$ & $\$ 1.03$ & $\$ 0.02$ & $\$ 1.05$ & $\$ 1.13$ & $25.56 \%$ \\
Offal & - & 1.000 & $20 \%$ & $\$ 1.03$ & $\$ 0.01$ & $\$ 1.04$ & $\$ 1.12$ & No \\
\hline \hline
\end{tabular}

The different post-split costs yield a different normal value for each part. In this example, comparing the constructed normal value for paws $(\$ 1.13)$ with the export price $(\$ 0.90)$, we find that paws are dumped at a margin of $25.56 \% .{ }^{155}$

\subsubsection{General comments}

As the examples highlight, the use of a weight-based or a value-based allocation method will likely make a huge difference on computed dumping margins. A weight-based allocation method will attribute the same pre-split-off $\operatorname{cost}^{156}$ to, for example, a kilogram of breast meat, a kilogram of leg quarters, or a kilogram of paws. Certainly, in countries like the US and the EU Member States, where people have a preference for chicken breast meat and such meat therefore commands a relatively high price as compared to leg quarters, let alone, paws, the weight-based approach will lead to a relatively low cost for the breast meat (and therefore generate a relatively high profit). It would also lead to greater cost allocation to leg quarters and paws and therefore increase the chance the investigating authority will find sales below cost.

Conversely, the US' value-based approach makes a finding of dumping less likely because, assuming that the exported products are costed as joint products, their export price will be compared with a cost which itself is price-based. If that price is a weighted average of both domestic and export sales, dumping could still be found depending on the price levels and volume of sales in the various markets. If the value-based allocation ratio is based on US sales prices, as was the practice of the three US respondents, a finding of dumping is unlikely because of the circular logic discussed above. Furthermore, if exported products such as paws are costed as by-products and the resulting costs reflect only specific processing costs and no pre-

$155(\$ 1.13-\$ 0.90) / \$ 0.90=0.2556$.

156 As we have seen above, the weight-based allocation method used by China also covered post-splitoff costs, but this will not be discussed further as it seems clearly wrong in that it attributes product-specific processing costs to products that do not benefit from the processing. 
split costs, a finding of dumping would be virtually impossible in cases such as the one under discussion where - because of differences in consumer tastes - paws may be sold at a relatively high price in the importing country market.

It is perhaps against this background that the Panel - while considering neither method in principle inherently unreasonable ${ }^{157}$ - nevertheless evaluated the appropriateness of MOFCOM's weight-based allocation method and largely ruled for the US on procedural grounds.

The above discussion leads us to certain basic conclusions. First, it seems to us that from an economic or conceptual perspective neither method is a panacea. On the one hand, a weight-based allocation of pre-split-costs to products as diverse as breast meat, leg quarters, and paws seems arbitrary and creates too much risk of leading to an improper allocation of costs in violation of Article 2.2.1.1, second sentence especially given the US producers' long history of using a value-based approach. On the other hand, if the primary cost of producing a chicken is feed, and the amount of feed attributable to each part is proportional to the part's weight, then the weight-based allocation may be preferred from an economic perspective.

Second, and from a legal perspective, Article 2.2.1.1 requires investigating authorities to consider all the evidence on the proper allocation of the costs including that which is made available by the exporters/producers provided such cost allocation methodologies have been historically used by the latter. The fact that the investigated exporters/producers have been using the proposed methodology historically and that this methodology indicates a standard practice in the exporting country industry, should be considered as an indication of the appropriateness of that methodology. It cannot be overlooked that the use of an allocation methodology is a means to an end and that the investigating authorities have the discretion of manipulating those means. Therefore, if an authority uses an allocation methodology which does not conform to the industry practice in the exporting country, its unreasonableness seems prima facie evident and it should not stand the test of Article 2.2.1.1, unless compelling evidence to the contrary can be presented. This is all the more so where the investigating authority's methodology would deviate from the requirement in Article 2.2 of the Anti-dumping Agreement to consider the costs of production 'in the country of origin'. Therefore, the cost allocation methodology historically used by the exporter/producer in the 'country of origin' should be considered 'proper' unless there are compelling reasons for the contrary. From a legal perspective, this conclusion seems clear. However, from an economic perspective, this view is most persuasive when the two markets have similar consumer preferences, but remains questionable when values (sales prices) dramatically differ because of the markedly different consumer preferences.

Last, a tricky legal issue seems to be whether an investigating authority has to accept costing of products such as paws on the basis of them being classified as

157 Panel Report, China-Broiler Products, para. 7.167. 
by-products in situations such as those present in this case where-because of differences in consumer tastes - their value may be low in the exporting country market, yet significant in the importing country market. To us it seems that, where as a result of such exports, the 'by-products' make a significant contribution to the exporter/producer's business, a value-based cost allocation method as used by the US producers is not prima facie unreasonable but a market-based representative economic value could also be considered.

\section{Concluding comments}

While the US was surely happy with the Panel's report, we think on other levels the original AD/CVD cases and the subsequent WTO dispute highlight real difficulties for the US and for US-China relations. First of all, in this case as with China-GOES the US is finding itself challenging practices that it appears that China has modeled on USDOC practices. A great irony in this dispute was that the US was forced to challenge China's use of the same practice - ignoring historical cost allocation submitted by foreign producers - that the USDOC has not only adopted but also forcefully defended many times. When the time comes that China learns how to properly conform its procedural practices (basically creation of an adequate paper trail) to WTO required procedures, US exporters will likely find themselves subject to prohibitive AD duties whose conceptual origins are the USDOC's. In a very real sense, the old adage 'the chickens have come home to roost' will then have come true.

Second, the original AD/CVD case is a striking example of tit-for-tat trade policy. After six months of deliberation, the US imposed China safeguard duties on passenger vehicle and light truck tires from China on 17 September 2009.158 China initiated its investigation into US chicken parts just 10 days later on 27 September 2009. This timing is no coincidence. The possibility of a Chinese AD investigation on US chicken parts exports was widely rumored in advance of the US' safeguard decision. In fact, just one day after the US announced the safeguard duties on passenger tires (and more than a week before the initiation of the case by China), National Public Radio ran a segment on the likely retaliation by China on chicken parts. ${ }^{159}$

The US tire tariff highlights how difficult it is to use discriminatory trade policy to boost a domestic industry and its workers. As shown in Figure 1 the tire tariff primarily resulted in trade diversion to the benefit of tire producers located in other countries.

158 This safeguard was the subject of an earlier WTO dispute, United States - Measures Affecting Imports of Certain Passenger Vehicle and Light Truck Tyres from China, WT/DS399/AB/R, adopted 5 October 2011.

159 Caitlin Kenney, 'Revenge of the Tariffs', National Public Radio Planet Money, 18 September 2009 at http://www.npr.org/blogs/money/2009/09/podcast_1.html. 
Figure 1. US imports of passenger vehicle and light truck tires

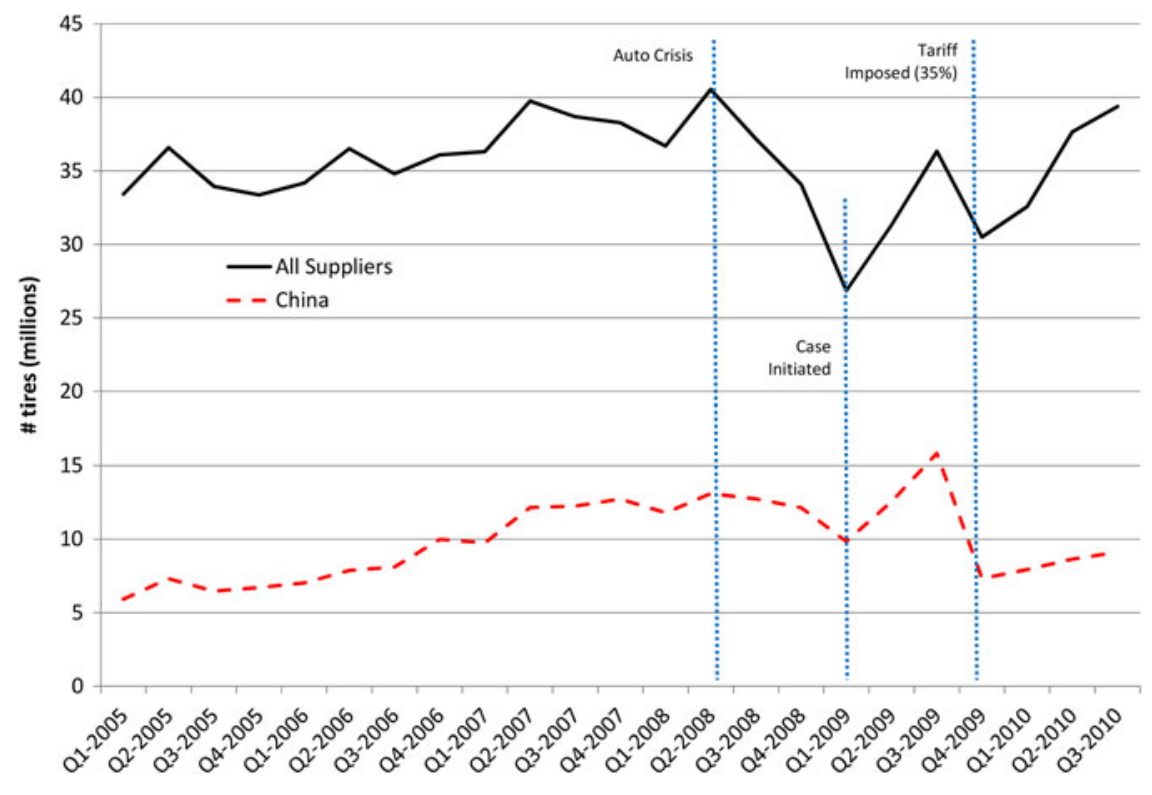

The tariffs did ultimately lead to a $30 \%$ reduction in made in China tire imports from 2009 to 2011 , but that didn't mean $30 \%$ more tires were produced in the U. S. It just meant that $30 \%$ more tires were imported from Canada; $110 \%$ more from South Korea; 44\% more from Japan; 152\% more from Indonesia; 154\% more from Thailand; $117 \%$ more from Mexico and 285\% more from low volume provider Taiwan'. ${ }^{160}$

Moreover, the tariff had little to no impact on US jobs. According to Hufbauer and Lowry (2012), the tire tariff saved 'a maximum of 1,200 jobs' at an annual cost of $\$ 900,000$ per job. ${ }^{161}$

To the extent that US policymakers reflect on the consequences of the tire tariff, the efficacy of discretionary protection would be further questioned when the impact of China's policy retaliation on US chicken producers is factored in. As shown in Figure 2, US shipments of chicken parts (measured either by overall volume or just chicken paws) fell by more than $85 \%$ in 2010 and by more than $90 \%$ in 2011 (relative to 2009 levels). In terms of dollar value, the tariffs reduced US exports of chicken parts to China by more than $\$ 600$ million in

160 Kenneth Rapoza, 'Obama's Half-Truth On China Tire Tariffs', 25 January 2012 at http://www. forbes.com/sites/kenrapoza/2012/01/25/obamas-half-truth-on-china-tire-tariffs/print/.

161 Gary C. Hufbauer and Sean Lowry, 'US Tire Tariffs: Saving Few Jobs at High Cost', Peterson Institute for International Economics Policy Brief No. PB12-9, April 2012. 
Figure 2. China imports of chicken parts and chicken paws (millions KG)

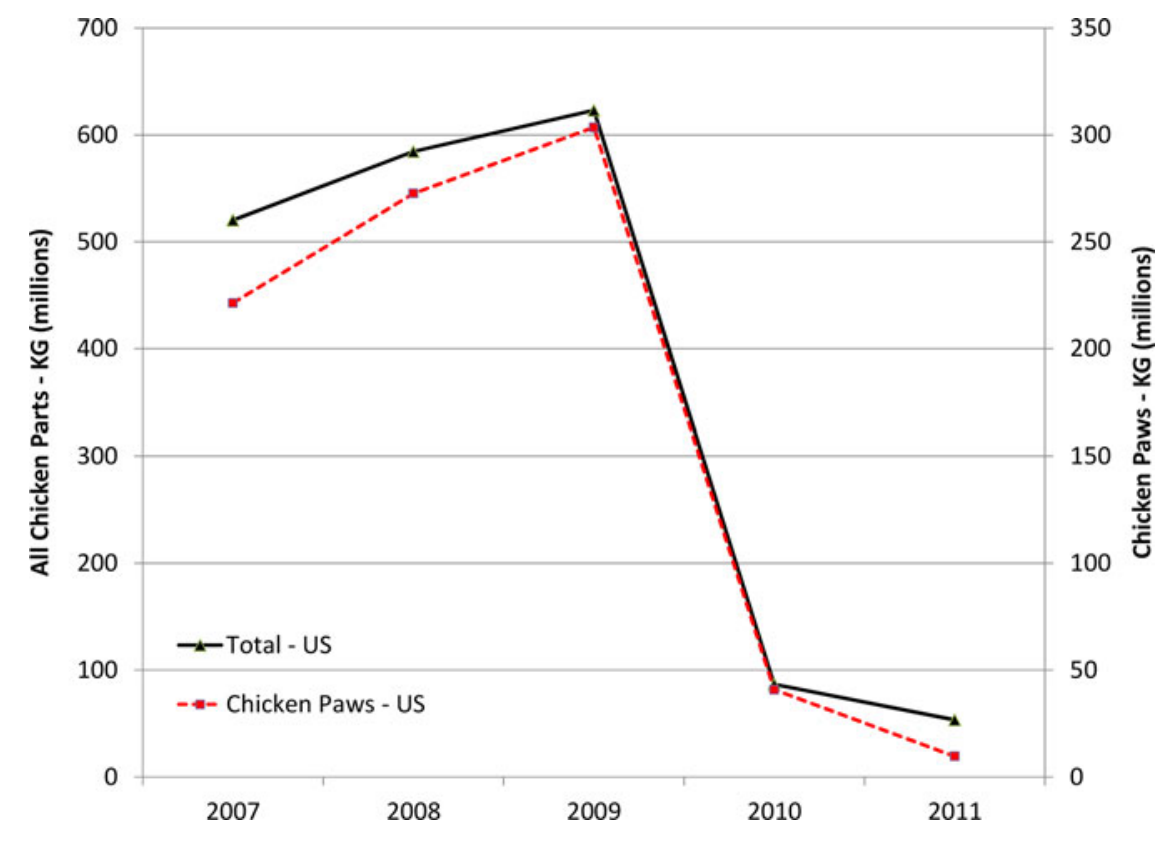

2010 and more than $\$ 700$ million in 2011. The fact that China lost at the WTO may be of secondary importance compared to the political message that was sent to the US - two can play this game.

Unfortunately - but not unexpectedly - the repercussions of the tire tariff cum China AD disputes do not end in China. After the Chinese case was initiated and $\mathrm{AD} / \mathrm{CVD}$ duties imposed, US producers began to export larger and larger volume of chicken parts to Mexico, among other countries (Figure 3). ${ }^{162}$

The sharp increase in imports from the US, led Mexico to initiate its own antidumping case against the US in February $2011 .{ }^{163}$ In July 2012, the Mexican Unit of Foreign Trade Practices (UPCI) made its final determination that US chicken parts were dumped and had caused material injury. The final AD

162 US politicians explicitly noted the impact of China's trade restraints as the reason for the trade deflection into Mexico. See, 'Senators Urge Dismissal of Mexican Antidumping Charges against US Chicken; NCC Lauds Latest Action', National Chicken Council, 2 April 2012, at http://www.nationalchickencouncil.org/senators-urge-dismissal-of-mexican-antidumping-charges-against-us-chicken-ncc-laudslatest-action/.

163 This $\mathrm{AD}$ induced change in trade pattern is referred to as 'trade deflection', See Chad P. Bown and Meredith A. Crowley, 'Trade Deflection and Trade Depression', Journal of International Economics v72, n1 (May 2007): 176-201. 
Figure 3. US exports of chicken parts to Mexico (millions KG)

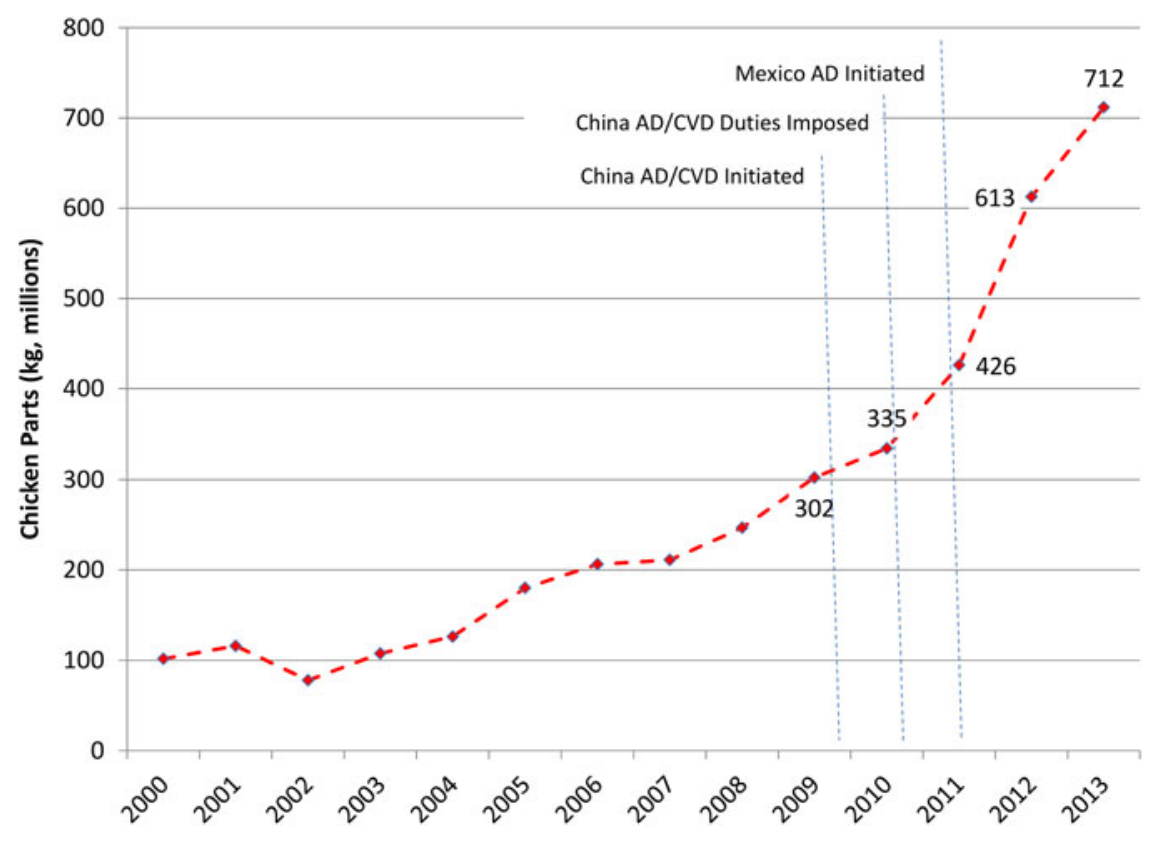

margins ranged from $25.7 \%$ to $127.5 \%$. Mexican authorities also rejected the US producers' preferred value-based methodology and instead used a weight-based method similar to that used by China. ${ }^{164}$ However, after substantial political pressure from the US, the Mexican Government decided to postpone imposing the duties until the Mexican domestic supply situation normalized. ${ }^{165}$ While it appears the US was able to avoid a domino sequence of $\mathrm{AD}$ duties on US chicken exports across destination markets, the myriad of costs imposed on the chicken industry are surely part of the collateral damage from the tire safeguard tariffs.

164 'Mexico puts duties on US chicken', World Poultry, 9 August 2012, at http://www.worldpoultry. net/Broilers/Markets-Trade/2012/8/Mexico-puts-duties-on-US-chicken-WP010737W/; 'WTO rejects China's duties on imports of U.S. chicken', Agri-Pulse, 2 August 2013, at http://www.agri-pulse.com/ WTO-rejects-Chinas-duties-on-imports-of-US-Chicken-08022013.asp.

165 'Mexico postpones chicken-leg import duties', 8 September 2012, at http://antidumping.vn/news/ 2012-08-09/mexico-postpones-chicken-leg-import-duties. 